\title{
Synthesis and Molecular Modeling Study of Two Bromo-Dimethoxybenzaldehydes
}

\author{
Igor D. Borges, ${ }^{a}$ Angélica Navarrete, ${ }^{b}$ Gerardo Aguirre, ${ }^{\circledR} * b$ Antônio S. N. Aguiar, ${ }^{c}$ \\ Solemar S. Oliveira, ${ }^{c}$ Ademir J. Camargo ${ }^{c}$ and Hamilton B. Napolitano ${ }^{\circledR *, a, c}$ \\ ${ }^{a}$ Laboratório de Novos Materiais, Universidade Evangélica de Goiás, 75083-515 Anápolis-GO, Brazil \\ ${ }^{b}$ Centro de Graduados e Investigación en Química, Tecnológico Nacional de México/IT de Tijuana, \\ 22500-000 Tijuana-B.C., Mexico \\ ${ }^{c}$ Grupo de Química Teórica e Estrutural de Anápolis, Universidade Estadual de Goiás, \\ 75001-970 Anápolis-GO, Brazil
}

\begin{abstract}
This work describes the synthesis, molecular structure, and packaging of the compounds 6-bromo-2,3-dimethoxybenzaldehyde (6-BRB) and 5-bromo-2,3-dimethoxybenzaldehyde (5-BRB). Characterization in the solid-state was carried out by X-ray diffraction, and the analysis of the interactions was described by the Hirshfeld surface, which helps in understanding the effect of replacing the bromine position in the aromatic ring. Both compounds (6-BRB and 5 -BRB) crystallized in the space group $\mathrm{P} 2 / \mathrm{c}$ and are stabilized with $\mathrm{C}-\mathrm{HO}$ interactions, but only the 6-BRB has a halogen-type interaction. Theoretical calculations, carried out by the density functional theory at the CAM-B3LYP/6-311++G(d,p) level of theory in gas phase, provided information on their electronic properties. The geometric properties were compared to experimental data, and the analyses of the frontier molecular orbitals and the molecular electrostatic potential (MEP) maps were obtained to predict the physical-chemical properties. The supramolecular arrangements were analyzed throughout complexation interactions and corrected by counterpoise method. Hyperconjugation energies were employed to examine the stability of the intermolecular interactions of the compounds. The interaction intensities were determined through the topological parameters obtained through the quantum theory of atoms in molecules model.
\end{abstract} QTAIM

Keywords: bromo-dimethoxybenzaldehyde, X-ray diffraction, molecular modeling, DFT,

\section{Introduction}

The brominated methoxyphenyl moiety is widely encountered in natural alkaloids, such as convolutamines, amathamides, and volutamides. ${ }^{1}$ This important class of compounds exhibits an array of biological properties, including antibacterial, antifungal, and antitumor activity. ${ }^{2,3}$ In this context, it has been found that the biological activity depends on the bromination of the methoxyphenyl unit. ${ }^{4,5}$ In particular, we are interested in the use of methoxyaldehydes brominated in different positions as building blocks for the synthesis of these natural alkaloids and derivatives. Out of a series of compounds, two brominated 2,3-dimethoxybenzaldehydes were suitable for study in the solid state.

*e-mail: gaguirre@tectijuana.mx; hamilton@ueg.br

Editor handled this article: José Walkimar M. Carneiro
With the increased understanding of their structure and structure-activity relationships, it has become possible to create new designs and fine-tune molecular functional structures by choosing the nature of the molecules involved, increasingly motivating the synthetic production of compounds. ${ }^{6,7}$ The understanding of noncovalent interactions between molecules is advantageous for the design of new crystalline materials, in which hydrogen bonding provides an additional stabilizing effect for the crystal structure..$^{8-10}$ Among these compounds, those which present a halogen bond have their potential for useful applications described in the literature in the areas of crystal engineering, material science, nonlinear optics, biochemical chemistry, and medicine. ${ }^{6,11-14}$ This class of interactions plays a fundamental role, for example, by establishing a halogen bond, acting as protein-ligand complexes. ${ }^{13,15}$ Halogen bonds are directional interactions between a halogen atom (chlorine, bromine, and iodine) and 
a free electron pair from a Lewis base, where the distance between the two atoms is less than the sum of their van der Waals radii. They can be classified as a noncovalent interaction, which, due to its specificity, can influence the crystal packing. ${ }^{6,13,16}$

Although these are specific intermolecular noncovalent interactions, they considerably influence the stabilization of crystalline states. Density functional theory (DFT) is an approach to quantum mechanics that provides important descriptors for understanding molecular structure based on the electron density of molecular systems. ${ }^{17,18}$ Through quantum mechanics calculations, it is possible to predict important information about the molecular and electronic structure of chemical compounds. ${ }^{19}$ Furthermore, the molecular structure, interactions, and supramolecular arrangement were characterized by geometric and topological parameters through Hirshfeld surfaces (HS), to understand crystal packaging and help future correlations and structure-activity applications. This theoretical study contains considerable information regarding the replacement of bromine, which can be very important for the design and synthesis of new materials containing halogenated compounds.

\section{Experimental}

\section{Synthesis and crystallization}

The synthesis ${ }^{20}$ of 6-bromo-2,3-dimethoxybenzaldehyde (6-BRB) (2) was achieved through bromination of 2,3-dimethoxybenzaldehyde (1) with $N$-bromosuccinimide (NBS), as depicted in Scheme 1. The synthesis of 5-bromo-2,3-dimethoxybenzaldehyde (5-BRB) (5) was obtained through two steps. First, $o$-vainillin (3) was subjected to molecular bromination to obtain 5-bromo2-hydroxy-3-methoxybenzaldehyde (4). Subsequently, methylation with methyl iodide produced 5-bromo2,3-dimethoxybenzaldehyde (5), as depicted in Scheme 2. All reagents were purchased in the highest quality available and were used without further purification. ${ }^{1} \mathrm{H}$ and ${ }^{13} \mathrm{C}$ nuclear magnetic resonance (NMR) spectra were recorded using a Bruker Avance $400 \mathrm{MHz}$ Spectrometer (Tijuana, B.C. Mexico) with tetramethylsilane (TMS) in $\mathrm{CDCl}_{3}$ as an internal standard. The chemical shifts are expressed in ppm and the coupling constants $(J)$ in hertz. Electronic impact mass spectra were obtained by direct insertion in an Agilent 5975C mass spectrometer (Tijuana, Mexico). Infrared spectra were obtained using $\mathrm{NaCl}$ windows on a FT-IR 1600 spectrophotometer (Tijuana, Mexico). Melting points were determined on a Fisher-Johns (Tijuana, Mexico) melting point apparatus and were uncorrected.

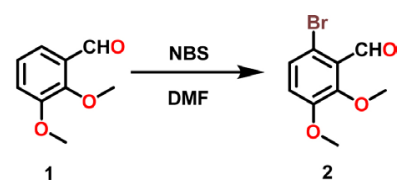

Scheme 1. Synthetic scheme for 6-BRB.

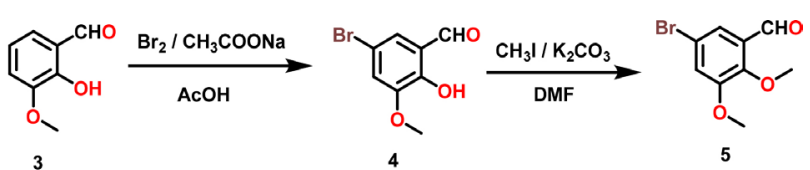

Scheme 2. Synthetic scheme for 5-BRB.

Synthesis of 6-bromo-2,3-dimethoxybenzaldehyde (2)

To a solution of 2,3-dimethoxybenzaldehyde (1) $(3.0 \mathrm{~g}, 18 \mathrm{mmol})$ in dimethylformamide (DMF) $(80 \mathrm{~mL})$, NBS (4.8 g, $27 \mathrm{mmol})$ dissolved in DMF (100 mL) was added dropwise over a period of $30 \mathrm{~min}$. After $48 \mathrm{~h}$ of stirring, the solution was poured into ice and water $(500 \mathrm{~mL})$. The resulting precipitate was collected by filtration and washed thoroughly with water, producing 6-bromo-2,3-dimethoxybenzaldehyde (2) in the form of a white powder $(60 \%)$. Crystals were obtained by slow evaporation of a dichloromethane solution. Colorless crystals: mp $75-77{ }^{\circ} \mathrm{C} ;{ }^{1} \mathrm{H}$ NMR $\left(400 \mathrm{MHz}, \mathrm{CDCl}_{3}\right) \delta 10.31$ $(\mathrm{s}, 1 \mathrm{H}), 7.31(\mathrm{~d}, J 8.7 \mathrm{~Hz}, 1 \mathrm{H}), 6.94(\mathrm{~d}, J 7.5 \mathrm{~Hz}, 1 \mathrm{H}), 3.91$ (s, 3H), 3.87 (s, 3H) (Figure S1, Supplementary Information (SI) section); ${ }^{13} \mathrm{C}$ NMR (100 MHz, $\left.\mathrm{CDCl}_{3}\right) \delta 190.4,152.8$, 152.1, 129.3, 128.7, 117.6, 112.8, 62.3, 56.2 (Figure S2, SI section); FTIR (ATR) v / $\mathrm{cm}^{-1} 1685,1570,1468$ (Figure S3, SI section).

\section{Synthesis of 5-bromo-2,3-dimethoxybenzaldehyde (5)}

\section{5-Bromo-2-hydroxy-3-methoxybenzaldehyde (4)}

To a reaction mixture containing $o$-vainillin $(3)(1.0 \mathrm{~g}$, $6.58 \mathrm{mmol})$ and sodium acetate $(1.67 \mathrm{~g})$ in glacial acetic acid $(20 \mathrm{~mL})$, bromine $(1.16 \mathrm{~g}, 7.25 \mathrm{mmol})$ in acetic acid $(10 \mathrm{~mL})$ was added. After $1 \mathrm{~h}$, the solvent was removed under reduced pressure and the residue was washed with water and extracted with dichloromethane. The organic extract was washed with $2 \% \mathrm{Na}_{2} \mathrm{CO}_{3}$ and water and then dried over $\mathrm{MgSO}_{4}$. The solvent was evaporated under reduced pressure to give a residue which was purified by chromatography (hexane/ethyl acetate, 6:4), producing 5-bromo-2-hydroxy-3-methoxybenzaldehyde (4) in the form of a yellow powder (97\%). Crystals were obtained by slow evaporation of a dichloromethane solution. Pale yellow crystals: mp $124-126{ }^{\circ} \mathrm{C}$; ${ }^{1} \mathrm{H}$ NMR $(400 \mathrm{MHz}$, $\left.\mathrm{CDCl}_{3}\right) \delta 10.94(\mathrm{~s}, 1 \mathrm{H}), 9.84(\mathrm{~s}, 1 \mathrm{H}), 7.28(\mathrm{~d}, J 2.20 \mathrm{~Hz}, 1 \mathrm{H})$, $7.15(\mathrm{~d}, J 2.20 \mathrm{~Hz}, 1 \mathrm{H}), 3.90$ (s, 3H) (Figure S4, SI section); 
${ }^{13} \mathrm{C}$ NMR (100 MHz, $\left.\mathrm{CDCl}_{3}\right) \delta$ 195.4, 151.0, 149.4, 126.2, 121.5, 120.9, 111.1, 56.7 (Figure S5, SI section); FTIR (ATR) $v / \mathrm{cm}^{-1} 3211,1651,1580$ (Figure S6, SI section).

\section{5-Bromo-2,3-dimethoxybenzaldehyde (5)}

To a solution of 5-bromo-2-hydroxy-3-methoxybenzaldehyde (4) $(1.0 \mathrm{~g}, 4.3 \mathrm{mmol}, 1.0 \mathrm{~g})$ and $\mathrm{K}_{2} \mathrm{CO}_{3}$ $(0.893 \mathrm{~g})$ in dry DMF $(5 \mathrm{~mL})$, methyl iodide $(0.40 \mathrm{~mL}$, $6.50 \mathrm{mmol}$ ) was added, and the mixture was stirred for $4 \mathrm{~h}$ at room temperature. The reaction mixture was quenched with water, the organic phase extracted into diethyl ether, and dried over anhydrous sodium sulfate. The solvent was removed, producing 5-bromo-2,3dimethoxybenzaldehyde (5) in the form of a white solid (98\%). Crystals were obtained by slow evaporation of a dichloromethane solution. Colorless crystals: $\mathrm{mp} 75-77^{\circ} \mathrm{C}$; ${ }^{1} \mathrm{H}$ NMR $\left(400 \mathrm{MHz}, \mathrm{CDCl}_{3}\right) \delta 10.33(\mathrm{~s}, 1 \mathrm{H}), 7.51(\mathrm{~d}$, $J 2.34 \mathrm{~Hz}, 1 \mathrm{H}), 7.22(\mathrm{~d}, J 2.34 \mathrm{~Hz}, 1 \mathrm{H}), 3.97$ (s, 3H), 3.90 (s, 3H) (Figure S7, SI section); ${ }^{13} \mathrm{C} \mathrm{NMR}\left(100 \mathrm{MHz}, \mathrm{CDCl}_{3}\right)$ $\delta$ 188.7, 154.0, 152.0, 130.7, 121.9, 121.2, 117.1, 62.5, 56.5 (Figure S8, SI section); FTIR (ATR) $v / \mathrm{cm}^{-1} 1950,1685$, 1570 (Figure S9, SI section).

\section{Crystallographic analysis}

The single crystal X-ray diffraction (XRD) data of 6-BRB and 5-BRB were obtained using an AtlasS2 diffractometer (Agilent SuperNova, Tijuana, B.C. Mexico). The data collection, cell refinements and reduction were carried out via CrysAlis Pro software. ${ }^{21}$ The molecular structure was solved on SHELXT and refined on SHELXL through the OLEX2 platform. ${ }^{22-24}$ The hydrogen atoms were refined by the riding model with the individual isotropic displacement parameters or $\mathrm{U}_{\mathrm{iso}}(\mathrm{H})=1.5 \mathrm{U}_{\text {eq, }}$, according to the $\mathrm{C}-\mathrm{H}$ model $(0.93 \AA$ for aromatic groups and $0.96 \AA$ for methyl groups). The crystal-structure ellipsoid diagrams were generated from an Oak Ridge thermal ellipsoid plot (ORTEP) with thermal-motion probability ellipsoids on the average atomic sites, derived from the atomic displacement matrix, and all supramolecular representations were generated using Mercury. ${ }^{25-27}$ Furthermore, the hydrogen bonds and molecular interactions were checked by PLATON. ${ }^{28}$ Crystallographic information files were deposited in the Cambridge structural database. ${ }^{29}$

CrystalExplorer $17^{30}$ was used to plot the HS and their fingerprints. ${ }^{31-33}$ These surfaces are located in a region of the crystal space around the molecule, defined by a continuous weight function for a molecule in a crystal, with a specified weight function $\mathrm{W}(\mathrm{r})=0.5$, with the space in the crystal being divided into specific regions, and where the distribution of electrons summed over all the atoms in the molecule ( $\left.\rho_{\text {imolecule }}\right)$ dominates the corresponding sum over the crystal $\left(\rho_{\text {icrystal }}\right)$, which is located in a region of the crystalline space around the molecule..$^{31,34}$

The HS describes intermolecular interactions through color-scaled mapping that permits the identification and description of surface properties. ${ }^{31}$ On a HS, the $d_{\text {norm }}$ (normalized distance) is seen in red, white, and blue, where red indicates regions with short intermolecular contacts, white indicates contacts around the separation of the van der Waals radii interface, and blue indicates long contact distances..$^{35}$ The normalized distance is constructed by the surface distance to the closest exterior atom $\left(d_{e}\right)$, where the molecules act as the strongest intermolecular contact receptors, by the surface distance to the closest interior atom $\left(\mathrm{d}_{\mathrm{i}}\right)$, where the molecule acts as the strongest intermolecular donor contacts, and by the van der Waals radii of the internal and external atoms $\left(\mathrm{r}_{\mathrm{i}}^{\mathrm{vdW}}\right.$ and $\left.\mathrm{r}_{\mathrm{e}}^{\mathrm{vdW}}\right) .^{35}$

The shape index maps on HS can be used to identify the interactions involving the $\pi$ system ( $\pi \cdots \pi$ interactions) and the complementary hollows (red), where two molecular surfaces touch one another, and bumps (blue), indicating possible interactions, can be described using the shape index. This allows us to identify characteristic packaging modes and flat arrangements, defined as those in which the interval of $S$ is $[-1+1], K_{1}$ and $K_{2}$ are eigenvalues of the diagonalization of a hessian matrix and are related to the main curvatures of the surface. In addition, an analysis of intermolecular contacts and their contributions to the packaging of crystals, based on the combination of $d_{e}$ and $\mathrm{d}_{\mathrm{i}}$, can generate unique fingerprints for each molecule in the form of $2 \mathrm{D}$ plots, which summarize the percentage contribution to the nature and type of intermolecular interaction present in the molecule. ${ }^{33}$

\section{Molecular modeling calculations}

Theoretical calculations at CAM-B3LYP ${ }^{36 /}$ $6-311 \mathrm{G}++(\mathrm{d}, \mathrm{p})$ level of theory, as implemented in the Gaussian09, ${ }^{36}$ were carried out for compounds 6-BRB and 5-BRB in order to assess the electronic properties due to the change of the bromine atom position in the compound 2,3-dimethoxybenzaldehyde. The input of gas phase geometry optimization was taken from the X-ray diffraction data, and all the calculations were carried out without any constraint on atomic coordinates. The wave functions were optimized with the help of exchange and correlation functionals CAM-B3LYP and population balance equation (PBE), respectively. The geometric properties were compared with the crystallographic data.

Frontier molecular orbital (FMO) analysis was used to describe the reactivity and kinetics of the compounds. ${ }^{37,38}$ 
Molecular electrostatic potential (MEP) maps were obtained to verify the chemical properties throughout the electronic isodensities surfaces. ${ }^{36,39}$ Quantum theory of atoms in molecules (QTAIM), ${ }^{40-42}$ carried out by Multiwfn software, ${ }^{43}$ was used to analyze the types of interactions in the supramolecular arrangement of 6-BRB and 5-BRB. Natural bond orbital (NBO) analyses were carried out to estimate the intermolecular interactions stabilities in the crystalline solid-state. ${ }^{44,45}$ The hyperconjugation energies from an electron delocalization between donor (Lewis type) and acceptor orbitals (non-Lewis type) were estimated using the second-order perturbation.

\section{Results and Discussion}

\section{Solid state description}

The ORTEP diagram of 5-BRB and 6-BRB compounds (Figure 1) indicates that both molecular conformations are almost planar. Their crystallographic parameters are presented in Table 1, in which both compounds crystallized on the centrosymmetric monoclinic space group $P 2_{1} / \mathrm{n}$, with $\mathrm{Z}=4$ (one independent molecule in the asymmetric unit). In addition, other details such as bond distance, angles and dihedral angles are shown in Table 2, where the molecular coplanarity is indicated by $\mathrm{C}_{6}-\mathrm{C}_{1}-\mathrm{C}_{2}-\mathrm{C}_{3}$ and $\mathrm{C}_{7}-\mathrm{C}_{1}-\mathrm{C}_{2}-\mathrm{C}_{3}$, with the respective dihedral angles of $-0.5^{\circ}$ and $178.2^{\circ}$ for 6-BRB, and of $-0.1^{\circ}$ and $176.9^{\circ}$ for 5 -BRB. Furthermore, we have a noticeable change in the dihedral angles of $\mathrm{C}_{3}-\mathrm{C}_{4}-\mathrm{C}_{5}-\mathrm{Br}$, with values of $179^{\circ}$ for $6-\mathrm{BRB}$ and $-180^{\circ}$ for 5 -BRB, due to the intermolecular interaction of bromine, which shows the experimental and theoretical results.

The molecular structure skeletons of 6-BRB and 5 -BRB with their asymmetric units consist of one aromatic ring with a bromine radical, two methyl groups and one carbonyl. The crystal structure 6-BRB is stabilized by the intra and intermolecular interaction $\mathrm{C}-\mathrm{H} \cdots \mathrm{O}$ and the halogen bond $\mathrm{Br} \cdots \mathrm{Br}$, while in structure 5-BRB there

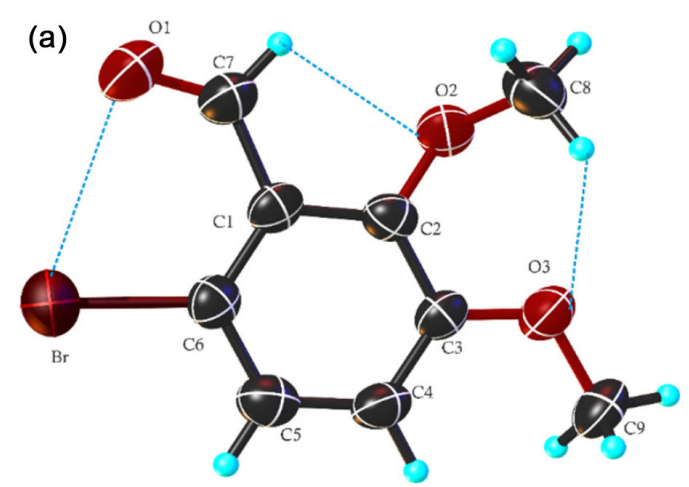

Table 1. Crystallographic data and structure refinement for 6-BRB and 5 -BRB

\begin{tabular}{|c|c|c|}
\hline Crystal data & 6-BRB & $5-\mathrm{BRB}$ \\
\hline Chemical formula & $\mathrm{C}_{9} \mathrm{H}_{9} \mathrm{BrO}_{3}$ & $\mathrm{C}_{9} \mathrm{H}_{9} \mathrm{BrO}_{3}$ \\
\hline Molecular weight $/\left(\mathrm{g} \mathrm{mol}^{-1}\right)$ & 245.07 & 245.07 \\
\hline Space group & $\mathrm{P} 2_{1} / \mathrm{n}$ & $\mathrm{P}_{2} / \mathrm{n}$ \\
\hline $\mathrm{a}, \mathrm{b}, \mathrm{c} / \AA$ & $\begin{array}{c}4.1252(2), \\
16.1692(10), \\
14.0678(7)\end{array}$ & $\begin{array}{c}3.96130(10) \\
15.5468(2) \\
15.7545(2)\end{array}$ \\
\hline$\alpha, \beta, \gamma /$ degree & $90,92.606(5), 90$ & $90,94.8650(10), 90$ \\
\hline $\mathrm{V} / \AA^{3}$ & $937.38(9)$ & $966.75(3)$ \\
\hline $\mathrm{Z}$ & 4 & 4 \\
\hline Radiation type & Mo K $\alpha$ & $\mathrm{Cu} \mathrm{K} \alpha$ \\
\hline$\mu / \mathrm{mm}^{-1}$ & 4.355 & 5.597 \\
\hline $\mathrm{R}[\mathrm{F} 2>2 \sigma(\mathrm{F} 2)]$ & 0.0581 & 0.0263 \\
\hline$w R(F 2)$ & 0.1576 & 0.0693 \\
\hline S & 1.037 & 1.033 \\
\hline No. of reflections & 2321 & 1844 \\
\hline No. of parameters & 120 & 120 \\
\hline
\end{tabular}

6-BRB: 6-bromo-2,3-dimethoxybenzaldehyde; 5-BRB: 5-bromo2,3-dimethoxybenzaldehyde; a,b,c and $\alpha, \beta, \gamma$ : unit cell dimensions; $\mathrm{Z}$ : number of molecules in the asymmetric unit; $\mathrm{V}$ : volume; S: goodnessof-fit parameter; F2: squared structure factor; wR2: weighted R-factor.

are the intermolecular interactions of type $\mathrm{C}-\mathrm{H} \cdots \mathrm{O}$. All interaction parameters are shown in Tables 3 and 4.

The packaging diagram in Figure 2 a shows the 6-BRB structure, in which there is a halogen interaction (Table 3) $\mathrm{Br} \cdots \mathrm{Br}$ connecting two molecules. In addition, the hydrogen bonds $\mathrm{C}_{8}-\mathrm{H}_{8 \mathrm{~B}} \cdots \mathrm{O}_{2}$ (Table 4) form a tetramer arrangement connected by $\pi \cdots \pi$ interactions, which govern and stabilize the supramolecular packaging $C_{1}^{1}(3)$ in [100] direction. In Figure 2b, the motifs in the crystal structure for the 5-BRB structure are shown. Note that a crystalline structure is stabilized by intermolecular interactions (Table 4) and $\pi \cdots \pi$ interactions, since the $\mathrm{C}-\mathrm{H}$ groups are donors of hydrogen bonds $\mathrm{C}_{4}-\mathrm{H}_{4} \cdots \mathrm{O}_{1}$ be defined as $\mathrm{C}_{1}^{1}(7)$, and contains a long carbonyl group on the c axis,

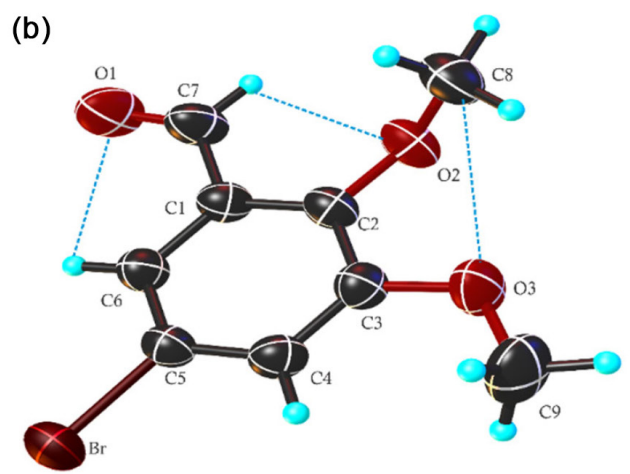

Figure 1. ORTEP diagram for (a) 6-BRB and (b) 5-BRB. The ellipsoids are represented at a 50\% probability level with the atomic numbering scheme. The hydrogen atoms are represented by spheres with arbitrary radii. 
Table 2. Relevant experimental and theoretical bond length, bond angles and dihedral angles for 6-BRB and 5-BRB

\begin{tabular}{|c|c|c|c|c|c|c|c|}
\hline \multicolumn{4}{|c|}{ 6-BRB } & \multicolumn{4}{|c|}{ 5-BRB } \\
\hline Bond length & $\mathrm{XRD} / \AA \AA$ & CAM-B3LYP / $\AA$ & $\mathrm{PBE} / \AA$ & Bond length & $\mathrm{XRD} / \AA$ & CAM-B3LYP / Å & $\mathrm{PBE} / \AA$ \\
\hline $\mathrm{Br}-\mathrm{C}_{6}$ & $1.892(4)$ & 1.899 & 1.911 & $\mathrm{Br}-\mathrm{C}_{5}$ & $1.897(2)$ & 1.902 & 1.916 \\
\hline $\mathrm{C}_{1}-\mathrm{C}_{2}$ & $1.414(6)$ & 1.400 & 1.420 & $\mathrm{C}_{1}-\mathrm{C}_{2}$ & $1.386(3)$ & 1.390 & 1.409 \\
\hline $\mathrm{C}_{1}-\mathrm{C}_{6}$ & $1.398(6)$ & 1.403 & 1.417 & $\mathrm{C}_{1}-\mathrm{C}_{6}$ & $1.399(3)$ & 1.398 & 1.411 \\
\hline $\mathrm{C}_{2}-\mathrm{C}_{3}$ & $1.397(7)$ & 1.403 & 1.417 & $\mathrm{C}_{2}-\mathrm{C}_{3}$ & $1.404(3)$ & 1.409 & 1.423 \\
\hline $\mathrm{C}_{2}-\mathrm{O}_{2}$ & $1.374(5)$ & 1.362 & 1.372 & $\mathrm{C}_{2}-\mathrm{O}_{2}$ & $1.370(3)$ & 1.361 & 1.370 \\
\hline $\mathrm{C}_{3}-\mathrm{O}_{3}$ & $1.368(5)$ & 1.355 & 1.367 & $\mathrm{C}_{3}-\mathrm{O}_{3}$ & $1.362(3)$ & 1.354 & 1.365 \\
\hline $\mathrm{C}_{5}-\mathrm{C}_{6}$ & $1.382(7)$ & 1.380 & 1.392 & $\mathrm{C}_{5}-\mathrm{C}_{6}$ & $1.365(3)$ & 1.372 & 1.384 \\
\hline $\mathrm{C}_{7}-\mathrm{O}_{1}$ & $1.175(6)$ & 1.204 & 1.221 & $\mathrm{C}_{7}-\mathrm{O}_{1}$ & $1.205(3)$ & 1.206 & 1.223 \\
\hline $\mathrm{C}_{3}-\mathrm{C}_{4}$ & $1.385(6)$ & 1.386 & 1.399 & $\mathrm{C}_{3}-\mathrm{C}_{4}$ & $1.376(3)$ & 1.386 & 1.400 \\
\hline $\mathrm{C}_{4}-\mathrm{C}_{5}$ & $1.384(6)$ & 1.394 & 1.400 & $\mathrm{C}_{4}-\mathrm{C}_{5}$ & $1.393(3)$ & 1.394 & 1.405 \\
\hline $\mathrm{C}_{8}-\mathrm{O}_{2}$ & $1.430(6)$ & 1.428 & 1.443 & $\mathrm{C}_{8}-\mathrm{O}_{2}$ & $1.434(3)$ & 1.428 & 1.444 \\
\hline $\mathrm{C}_{9}-\mathrm{O}_{3}$ & $1.440(5)$ & 1.417 & 1.430 & $\mathrm{C}_{9}-\mathrm{O}_{3}$ & $1.427(3)$ & 1.417 & 1.431 \\
\hline MAPD & & 0.762 & 1.084 & MAPD & & 0.399 & 0.969 \\
\hline Bond angle & XRD / degree & CAM-B3LYP / $\AA$ & $\mathrm{PBE} / \AA$ & Bond angle & XRD / degree & CAM-B3LYP / & PBE / degree \\
\hline $\mathrm{C}_{2}-\mathrm{C}_{1}-\mathrm{C}_{7}$ & $116.9(4)$ & 116.680 & 116.871 & $\mathrm{C}_{2}-\mathrm{C}_{1}-\mathrm{C}_{7}$ & $119.8(2)$ & 120.327 & 120.467 \\
\hline $\mathrm{C}_{6}-\mathrm{C}_{1}-\mathrm{C}_{7}$ & $124.9(4)$ & 124.792 & 124.886 & $\mathrm{C}_{6}-\mathrm{C}_{1}-\mathrm{C}_{7}$ & $119.5(2)$ & 118.825 & 118.610 \\
\hline $\mathrm{C}_{1}-\mathrm{C}_{2}-\mathrm{C}_{3}$ & $120.8(4)$ & 121.098 & 120.947 & $\mathrm{C}_{1}-\mathrm{C}_{2}-\mathrm{C}_{3}$ & $119.7(2)$ & 119.367 & 119.116 \\
\hline $\mathrm{C}_{1}-\mathrm{C}_{2}-\mathrm{O}_{2}$ & $119.0(4)$ & 119.188 & 118.721 & $\mathrm{C}_{1}-\mathrm{C}_{2}-\mathrm{O}_{2}$ & 119.6(2) & 119.570 & 119.140 \\
\hline $\mathrm{C}_{2}-\mathrm{C}_{3}-\mathrm{O}_{3}$ & $115.7(4)$ & 116.175 & 116.203 & $\mathrm{C}_{2}-\mathrm{C}_{3}-\mathrm{O}_{3}$ & $115.3(2)$ & 116.148 & 116.199 \\
\hline $\mathrm{Br}-\mathrm{C}_{6}-\mathrm{C}_{1}$ & $122.8(3)$ & 123.125 & 123.111 & $\mathrm{Br}-\mathrm{C}_{5}-\mathrm{C}_{4}$ & $117.5(2)$ & 118.477 & 118.286 \\
\hline $\mathrm{Br}-\mathrm{C}_{6}-\mathrm{C}_{5}$ & $116.3(3)$ & 116.575 & 116.224 & $\mathrm{Br}-\mathrm{C}_{5}-\mathrm{C}_{6}$ & $120.0(2)$ & 120.006 & 120.047 \\
\hline $\mathrm{C}_{1}-\mathrm{C}_{6}-\mathrm{C}_{5}$ & $120.9(4)$ & 120.283 & 120.665 & $\mathrm{C}_{1}-\mathrm{C}_{6}-\mathrm{C}_{5}$ & $118.2(2)$ & 118.876 & 118.834 \\
\hline $\mathrm{C}_{1}-\mathrm{C}_{7}-\mathrm{O}_{1}$ & $128.2(5)$ & 125.239 & 125.852 & $\mathrm{C}_{1}-\mathrm{C}_{7}-\mathrm{O}_{1}$ & $124.5(2)$ & 123.145 & 123.566 \\
\hline $\mathrm{C}_{2}-\mathrm{O}_{2}-\mathrm{C}_{8}$ & 115.3(3) & 116.264 & 116.322 & $\mathrm{C}_{2}-\mathrm{O}_{2}-\mathrm{C}_{8}$ & $115.6(2)$ & 116.726 & 116.747 \\
\hline $\mathrm{C}_{3}-\mathrm{O}_{3}-\mathrm{C}_{9}$ & $118.0(3)$ & 118.332 & 117.586 & $\mathrm{C}_{3}-\mathrm{O}_{3}-\mathrm{C}_{9}$ & $117.5(2)$ & 118.566 & 117.869 \\
\hline MAPD & & 0.503 & 0.401 & MAPD & & 0.584 & 0.569 \\
\hline Dihedral angle & XRD / degree & $\begin{array}{c}\text { CAM-B3LYP / } \\
\text { degree }\end{array}$ & $\mathrm{PBE} /$ degree & Dihedral angle & $\mathrm{XRD} /$ degree & $\begin{array}{c}\text { CAM-B3LYP / } \\
\text { degree }\end{array}$ & $\mathrm{PBE} /$ degree \\
\hline $\mathrm{C}_{6}-\mathrm{C}_{1}-\mathrm{C}_{2}-\mathrm{C}_{3}$ & $-0.5(6)$ & -0.229 & -0.065 & $\mathrm{C}_{6}-\mathrm{C}_{1}-\mathrm{C}_{2}-\mathrm{C}_{3}$ & $-0.1(3)$ & 0.509 & 0.479 \\
\hline $\mathrm{C}_{7}-\mathrm{C}_{1}-\mathrm{C}_{2}-\mathrm{O}_{2}$ & $-5.8(6)$ & -2.355 & -5.291 & $\mathrm{C}_{7}-\mathrm{C}_{1}-\mathrm{C}_{2}-\mathrm{O}_{2}$ & $-7.0(3)$ & -3.054 & -4.630 \\
\hline $\mathrm{C}_{7}-\mathrm{C}_{1}-\mathrm{C}_{2}-\mathrm{C}_{3}$ & $178.2(4)$ & -179.618 & 179.171 & $\mathrm{C}_{7}-\mathrm{C}_{1}-\mathrm{C}_{2}-\mathrm{C}_{3}$ & $176.9(2)$ & -179.216 & -179.874 \\
\hline $\mathrm{C}_{2}-\mathrm{C}_{1}-\mathrm{C}_{6}-\mathrm{C}_{5}$ & $1.4(7)$ & 0.338 & 0.940 & $\mathrm{C}_{2}-\mathrm{C}_{1}-\mathrm{C}_{6}-\mathrm{C}_{5}$ & $0.2(3)$ & 0.250 & 0.595 \\
\hline $\mathrm{C}_{6}-\mathrm{C}_{1}-\mathrm{C}_{7}-\mathrm{O}_{1}$ & $-6.8(9)$ & 17.412 & -2.126 & $\mathrm{C}_{6}-\mathrm{C}_{1}-\mathrm{C}_{7}-\mathrm{O}_{1}$ & $2.7(4)$ & 1.290 & -0.506 \\
\hline $\mathrm{O}_{2}-\mathrm{C}_{2}-\mathrm{C}_{3}-\mathrm{O}_{3}$ & $3.4(6)$ & 2.065 & 2.330 & $\mathrm{O}_{2}-\mathrm{C}_{2}-\mathrm{C}_{3}-\mathrm{O}_{3}$ & $2.8(3)$ & 2.176 & 2.273 \\
\hline $\mathrm{C}_{1}-\mathrm{C}_{2}-\mathrm{O}_{2}-\mathrm{C}_{8}$ & 109.4(4) & 110.473 & 115.904 & $\mathrm{C}_{1}-\mathrm{C}_{2}-\mathrm{O}_{2}-\mathrm{C}_{8}$ & $113.4(2)$ & 115.578 & 119.629 \\
\hline $\mathrm{C}_{2}-\mathrm{C}_{1}-\mathrm{C}_{6}-\mathrm{Br}$ & $-179.0(3)$ & -178.101 & -179.353 & $\mathrm{C}_{3}-\mathrm{C}_{4}-\mathrm{C}_{5}-\mathrm{Br}$ & $-180.0(2)$ & 179.811 & 179.746 \\
\hline MAPD & & 98.372 & 29.447 & MAPD & & 145.940 & 169.371 \\
\hline
\end{tabular}

6-BRB: 6-bromo-2,3-dimethoxybenzaldehyde; 5-BRB: 5-bromo-2,3-dimethoxybenzaldehyde; XRD: X-ray diffraction; PDE: population balance equation; MAPD: mean absolute percentage deviations.

Table 3. Geometric parameters of halogen bonding obtained from structural analysis for 6-BRB

\begin{tabular}{lccc}
\hline Interaction $\mathrm{X}_{1} \cdots \mathrm{X}_{2}$ & $\mathrm{~d}\left(\mathrm{X}_{1} \cdots \mathrm{X}_{2}\right) / \AA$ & Angle $\left(\mathrm{X}_{1} \cdots \mathrm{X}_{2}\right) /$ degree & Symmetry code \\
\hline $\mathrm{Br} \cdots \mathrm{O}_{2}$ & 3.025 & 157.5 & intramolecular \\
$\mathrm{Br} \cdots \mathrm{Br}$ & 3.540 & 161.0 & $(-x, 1-y,-z)$ \\
\hline
\end{tabular}


Table 4. Hydrogen-bond geometry obtained from structural analysis for 6-BRB and 5-BRB

\begin{tabular}{|c|c|c|c|c|c|}
\hline $\mathrm{D}-\mathrm{H} \cdots \mathrm{A}$ & $\mathrm{d}(\mathrm{D}-\mathrm{H}) / \AA$ & $\mathrm{d}(\mathrm{H} \cdots \mathrm{A}) / \AA$ & $\mathrm{d}(\mathrm{D} \cdots \mathrm{A}) / \AA$ & $\mathrm{d}(\mathrm{D}-\mathrm{H} \cdots \mathrm{A}) /$ degree & Symmetry code \\
\hline \multicolumn{6}{|c|}{ 6-BRB } \\
\hline $\mathrm{C}_{7}-\mathrm{H}_{7} \cdots \mathrm{O}_{2}$ & 0.93 & 2.36 & $2.753(6)$ & 105.1 & intramolecular \\
\hline $\mathrm{C}_{8}-\mathrm{H}_{8 \mathrm{~A}} \cdots \mathrm{O}_{3}$ & 0.96 & 2.47 & $3.009(5)$ & 115.3 & intramolecular \\
\hline$\underline{\mathrm{C}_{8}-\mathrm{H}_{8 \mathrm{~B}} \cdots \mathrm{O}_{2}}$ & 0.96 & 2.61 & $3.519(4)$ & 157.5 & $(-1+x, y, z)$ \\
\hline \multicolumn{6}{|c|}{ 5-BRB } \\
\hline $\mathrm{C}_{7}-\mathrm{H}_{7} \cdots \mathrm{O}_{2}$ & 0.93 & 2.47 & $2.803(3)$ & 101.5 & intramolecular \\
\hline $\mathrm{C}_{8}-\mathrm{H}_{8 \mathrm{~A}} \cdots \mathrm{O}_{3}$ & 0.96 & 2.45 & $2.953(3)$ & 112.4 & intramolecular \\
\hline $\mathrm{C}_{8}-\mathrm{H}_{8 \mathrm{~B}} \cdots \mathrm{O}_{2}$ & 0.96 & 2.59 & $3.516(4)$ & 161.8 & $(1+x, y, z)$ \\
\hline $\mathrm{C}_{9}-\mathrm{H}_{9 \mathrm{C}} \cdots \mathrm{O}_{1}$ & 0.96 & 2.50 & $3.454(4)$ & 173.5 & $(1 / 2-x, 1 / 2+y, 3 / 2-z)$ \\
\hline $\mathrm{C}_{4}-\mathrm{H}_{4} \cdots \mathrm{O}_{1}$ & 0.93 & 2.67 & $3.595(3)$ & 168.9 & $(1 / 2+x, 1 / 2-y, 1 / 2+z)$ \\
\hline
\end{tabular}

6-BRB: 6-bromo-2,3-dimethoxybenzaldehyde; 5-BRB: 5-bromo-2,3-dimethoxybenzaldehyde.

$\mathrm{C}_{8}-\mathrm{H}_{8 \mathrm{~B}} \cdots \mathrm{O}_{2}$ as $\mathrm{C}_{1}{ }^{1}(3)$, and $\mathrm{C}_{9}-\mathrm{H}_{9 \mathrm{C}} \cdots \mathrm{O}_{1}$ as $\mathrm{C}_{1}{ }^{1}(8)$, with a long carbonyl group along the $\mathrm{a}$ and $\mathrm{b}$ axes, respectively. These intermolecular interactions contribute to supramolecular arrangements, with a bifurcated interaction involving $\mathrm{O} 1$ in intermolecular interactions, and $\mathrm{C}_{9}-\mathrm{H}_{9 \mathrm{C}} \cdots \mathrm{O}_{1}$ and $\mathrm{C}_{4}-\mathrm{H}_{4} \cdots \mathrm{O}_{1}$ forming a tetramer. They also increase in the a and $\mathrm{c}$ axis directions, which can be described by the ring $\mathrm{R}_{4}{ }^{4}(24)$.

The HS contributes to understanding the crystalline packing, analyzing the intermolecular interactions, and recognizing predominant non-covalent interactions, identified by the red spots displayed by the $\mathrm{d}_{\text {norm }}$, thus identifying the regions. Mapped over $\mathrm{d}_{\text {norm }}$ (ranging from -0.0862 to $0.9988 \AA$ for $6-\mathrm{BRB}$ and from -0.1709 to $1.3021 \AA$ for 5-BRB) shows in Figure 3, that the structure of 6-BRB $\mathrm{C}_{8}-\mathrm{H}_{8 \mathrm{~B}} \ldots \mathrm{O}_{2}(1 \mathrm{a})$, and the halogen bond $\mathrm{Br} \cdots \mathrm{Br}(2 \mathrm{a})$ contribute to supramolecular packaging, while the compound 5-BRB is stabilized by hydrogen bonds, $\mathrm{C}_{8}-\mathrm{H}_{8 \mathrm{~B}} \cdots \mathrm{O}_{2}(1 \mathrm{~b}), \mathrm{C}_{9}-\mathrm{H}_{9 \mathrm{C}} \cdots \mathrm{O}_{1}(2 \mathrm{~b}), \mathrm{C}_{4}-\mathrm{H}_{4} \cdots \mathrm{O}_{1}(3 \mathrm{~b})$.

The shape index assists in the interpretation of the interactions that occur in the $\pi$ system. The $\pi \cdots \pi$ interaction, represented by the red and blue triangles (bow tie), is where

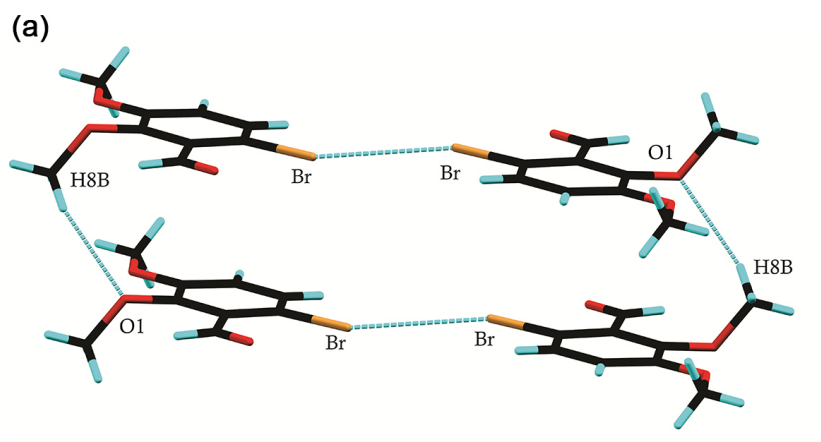

two aromatic rings overlap. For this interaction, the centroid of the aromatic rings for the compounds was calculated, with the distance between the two rings. For the 6-BRB structure (Figure 4a), the overlap appears at a distance of $4.125 \AA$, showing the contribution of these interactions in packaging and molecular stability, while in the 5-BRB (Figure 4b) we have a distance of $3.961 \AA$.

The relative surface area resulting from the contributions of each interaction that is exposed in the supramolecular arrangement is quantified by a fingerprint analysis, generated from the graph of $\left(\mathrm{d}_{\mathrm{e}} v s . \mathrm{d}_{\mathrm{i}}\right)$. The interactions are highlighted in the fingerprint graphs for structure 6-BRB (Figure 5a) and for structure 5-BRB (Figure 5b), in which most contributions are related to the $\mathrm{H} \cdot \cdots \mathrm{H}$ interaction -35.3 and $36.7 \%$, respectively, and the $\mathrm{H} \cdots \mathrm{O}$ interactions, 26.4 and $21.5 \%$, respectively. They are characterized by peaks at the bottom of the fingerprint graphs and indicate the $\mathrm{C}-\mathrm{H} \cdots \mathrm{O}$ interactions of the total HS. Another characteristic is the presence of $\mathrm{C} \cdots \mathrm{C}$ interactions: 7.3 and $6.2 \%$ present in the center, in addition to a noticeable difference in $\mathrm{Br}-\mathrm{Br}$, of 2.5 and $0.9 \%$, due to the interaction between

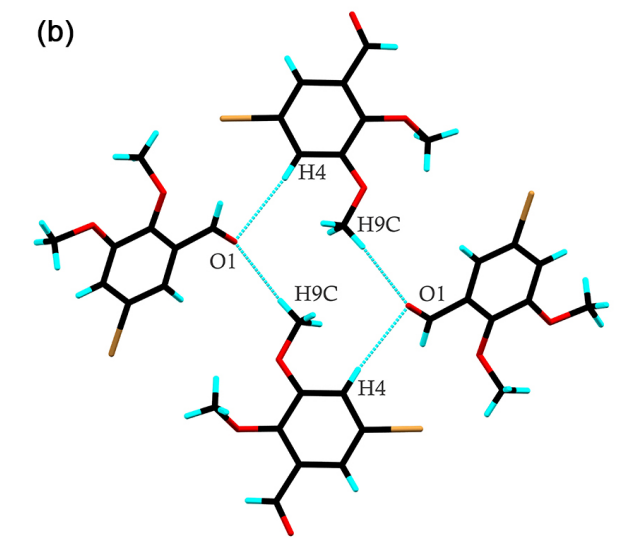

Figure 2. Representation of intermolecular interactions for (a) 6-BRB and (b) 5-BRB. 

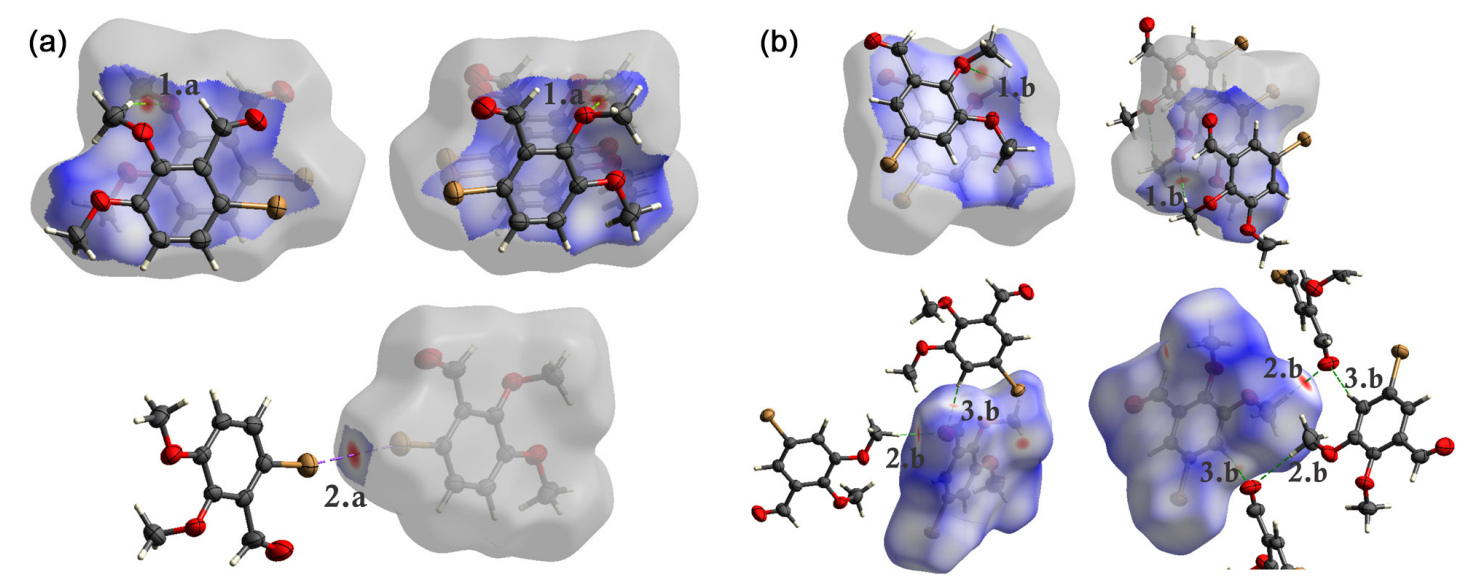

Figure 3. HS plotted for (a) (1a) $\mathrm{C}_{8}-\mathrm{H}_{8 \mathrm{~B}} \cdots \mathrm{O}_{2}$ and (2a) $\mathrm{Br} \cdots \mathrm{Br}$ for 6-BRB and (b) (1b) $\mathrm{C}_{8}-\mathrm{H}_{8 \mathrm{~B}} \cdots \mathrm{O}_{2}$, (2b) $\mathrm{C}_{9}-\mathrm{H}_{9 \mathrm{C}} \cdots \mathrm{O}_{1}$, (3b) $\mathrm{C}_{4}-\mathrm{H}_{4} \cdots \mathrm{O}_{1}$ for 5-BRB. Dotted lines were used to represent bonds.
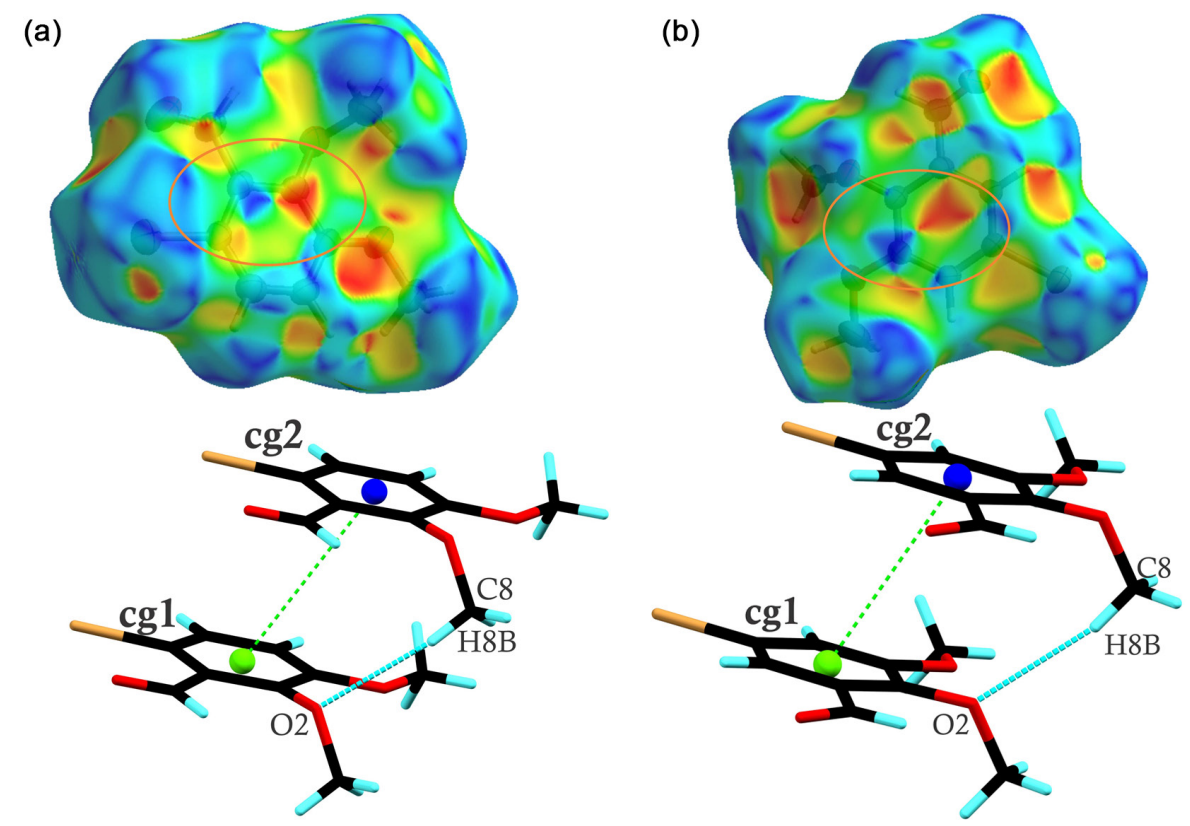

Figure 4. Shape index surfaces for evidencing $\pi \cdots \pi$ interactions and representation (a) 6-BRB (b) 5-BRB.

them in structure 6-BRB. Furthermore, the surfaces provide information about each donor-acceptor pair and allow us to measure how much the shape divides the surfaces into their scale of colors and stains.

\section{Molecular modeling analysis}

Table 2 shows the optimized geometric parameters in the gas phase for 6-BRB and 5-BRB at CAM-B3LYP/6$311++\mathrm{G}(\mathrm{d}, \mathrm{p})$ level of theory. The mean absolute percentage deviations (MAPD) for both compounds were calculated using the equation:

$\mathrm{MAPD}=\frac{100}{\mathrm{n}} \sum_{\mathrm{i}=1}^{\mathrm{n}}\left|\frac{\chi_{\mathrm{XRD}}-\chi_{\mathrm{CAM}-\mathrm{B} 3 \mathrm{LYP}}}{\chi_{\mathrm{XRD}}}\right|$ where $\chi_{\mathrm{XRD}}$ stands for the geometric parameters taken from the XRD data and $\chi_{\text {САM-B3LYP }}$ represents the geometric parameters obtained from the theoretical calculations.

The MAPD values obtained for the bond length in 6 -BRB were 0.76 and $1.08 \%$ for the functionals CAM-B3LYP and PBE (a ratio of 1:1.4), respectively; for $5-B R B$, the MAPD values were 0.40 and $0.97 \%$ (a ratio of 1:2.4), respectively. These results show that both functionals describe molecular systems similarly; however, the functional CAM-B3LYP resulted in more accurate values for the geometry of both compounds, when compared to the experimental values. The coefficients of determination show that the bond lengths in 6-BRB are described with $99.29 \%$ accuracy against $99.24 \%$, respectively for the functionals CAM-B3LYP and PBE; for 5-BRB, the bond lengths are described as 99.83 and 

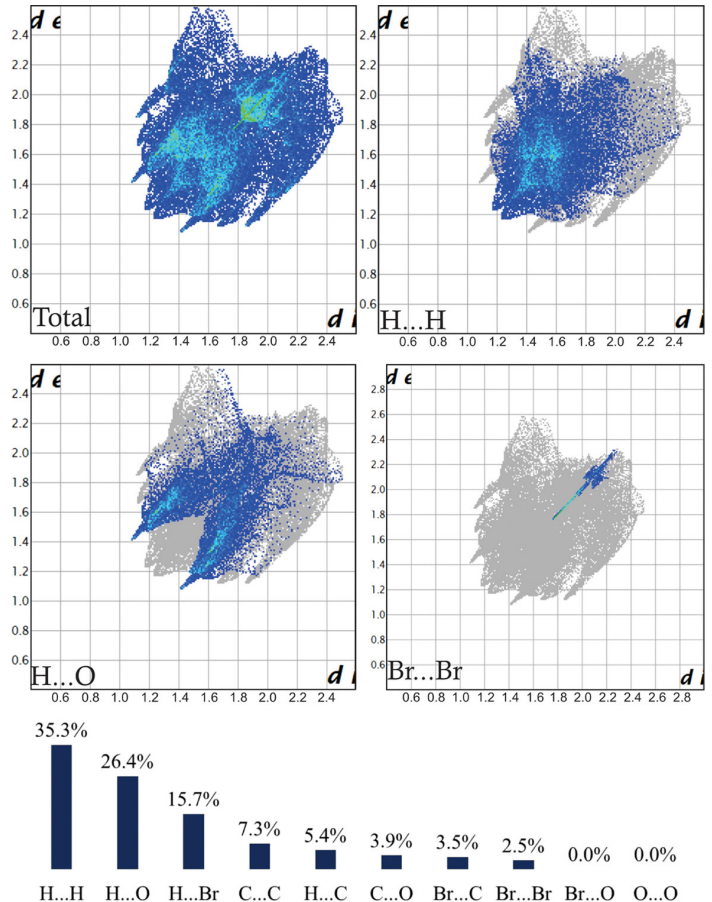

(a)
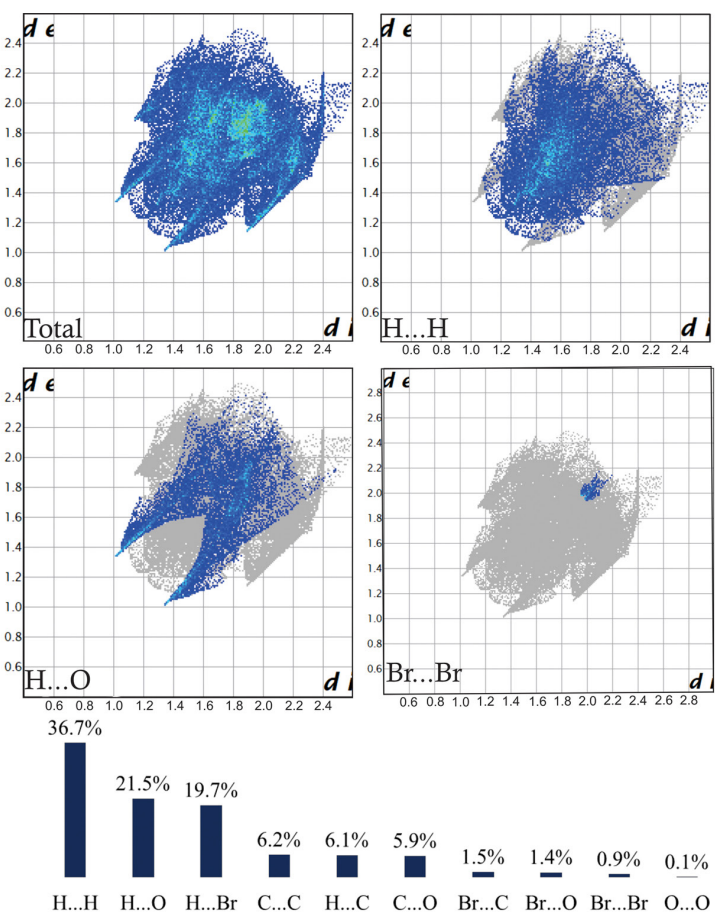

(b)

Figure 5. Fingerprint plots for (a) 6-BRB and (b) 5-BRB.

99.76\% for the respective functionals. The coefficients of determination obtained show that the bond angles are better explained by the functional PBE (97.18\%) in the 6-BRB, in relation to the CAM-B3LYP functional (96.03\%), while in the 5-BRB, the CAM-B3LYP functional better explains the angles $(95.58 \%)$ in relation to the functional PBE $(94.42 \%)$. The angle $\mathrm{C}_{1}-\mathrm{C}_{7}-\mathrm{O}_{1}$ in 6-BRB had the highest percentage relative deviation, with a value of $2.3 \%$ when calculated with the functional CAM-B3LYP, while the value of $1.8 \%$ was observed when calculated with the functional PBE. Figures 6 and 7 visually compare the lengths and angles of theoretical and experimental bonds for compounds 6-BRB and 5-BRB.

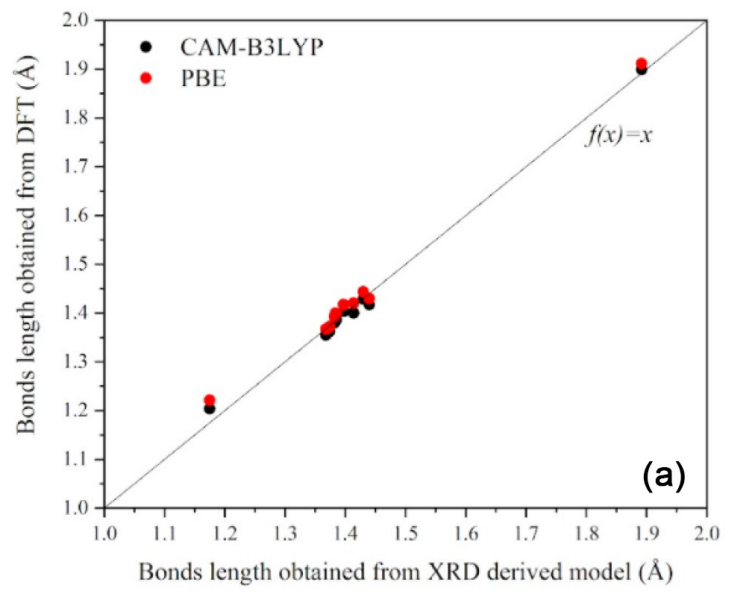

The bromine atom bonded to the $\mathrm{C}_{6}$ carbon in the 6-BRB molecule exerts a repulsive force on the $\mathrm{O}_{1}$ atom from the carbonyl group, increasing the $\mathrm{C}_{1}-\mathrm{C}_{7}-\mathrm{O}_{1}$ bond angle slightly when compared to the 5-BRB. The dihedral angles show that the substituent groups on the aromatic ring are in the same plane, except for the methyl groups attached to the $\mathrm{O}_{2}$ atom, which are outside that plane. The electron density $\rho(\mathbf{r})$ is the fundamental variable in DFT,,$^{17,18}$ and it allows the definition of some important chemical concepts, such as chemical reactivity of molecules. ${ }^{37}$ The highest occupied molecular orbital (HOMO) and lowest unoccupied molecular orbital (LUMO) enable us to obtain valuable chemical descriptors, such as chemical potential,

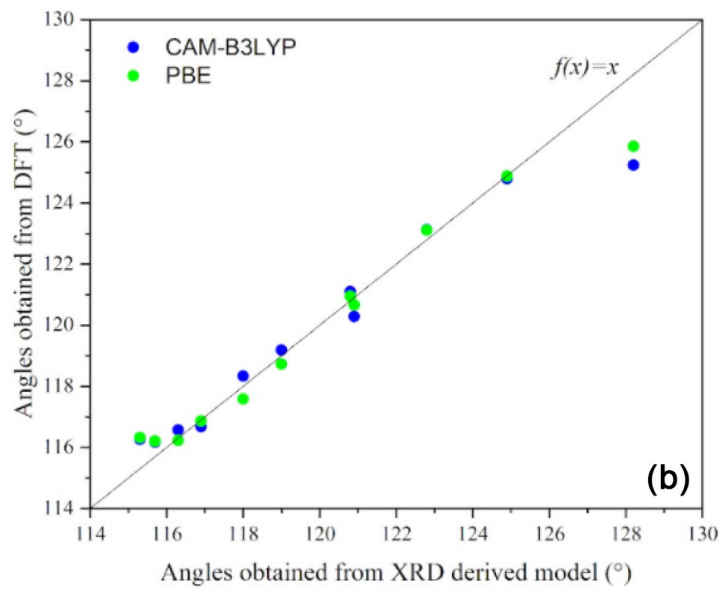

Figure 6. Plotting of theoretical geometric parameters versus experimental values taken from XRD data for the compound 6-BRB. 

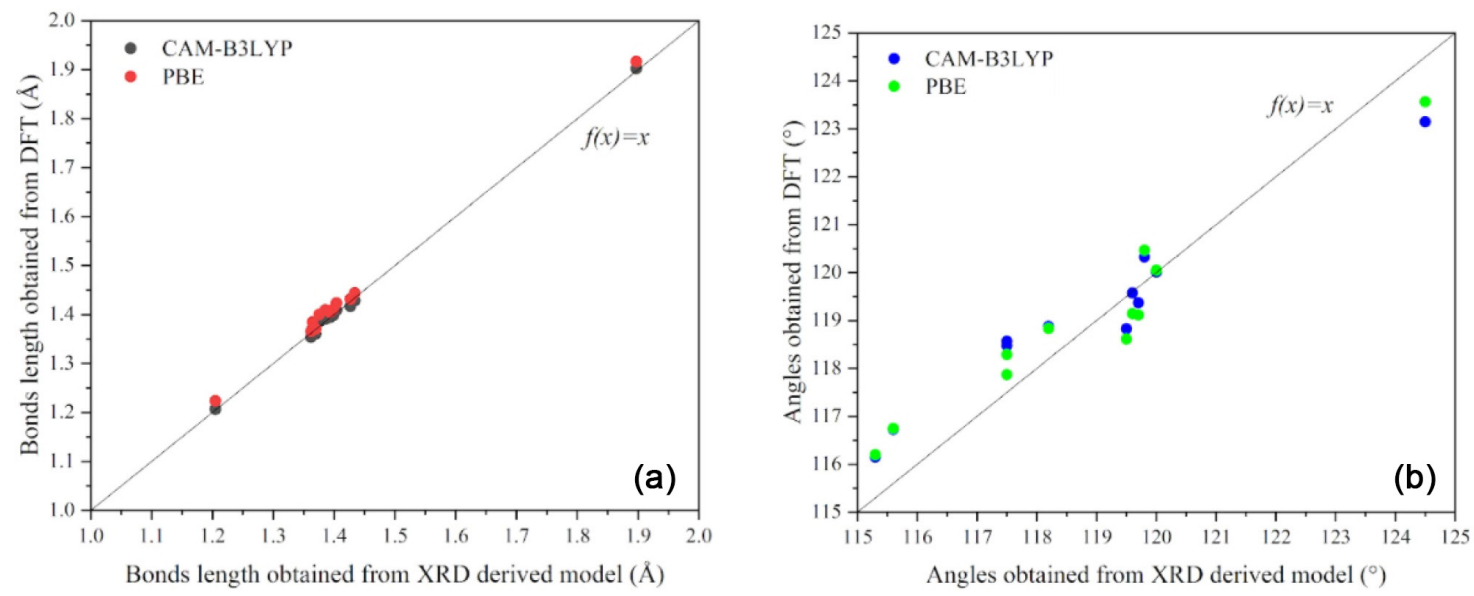

Figure 7. Plotting of theoretical geometric parameters versus experimental values taken from XRD data for the compound 5-BRB.

hardness, and the global electrophilicity index. These descriptor indices allow us to understand the chemical reactivity and kinetic stability of molecules. ${ }^{19}$

Figures 8 and 9 show the HOMO and LUMO energies obtained at the CAM-B3LYP/6-311++G(d,p) level of theory for the compounds 6-BRB and 5-BRB, respectively. HOMO energy is associated with a molecule's ability to donate electrons, while LUMO energy is related to the molecule's ability to receive electrons. The larger LUMO-HOMO gap energy ( $\left.\Delta \mathrm{E}_{\text {номо-Luмо }}\right)$ always refers to higher kinetic stability and lower chemical reactivity. The calculated gap values for both compounds are -161.40 and $-162.90 \mathrm{kcal} \mathrm{mol}^{-1}$, respectively. Therefore, we can conclude that both molecules are chemically stable. The quantum descriptors electronegativity $(\chi)$, chemical potential $(\mu=-\chi)$, hardness $(\eta)$, softness $(\sigma=1 / \eta)$, and the global electrophilicity index ${ }^{46}(\omega)$ can be obtained using the expressions:

$\mu=\left(\frac{\partial \mathrm{E}}{\partial \mathrm{N}}\right)_{v(\mathrm{r})}=\frac{-\mathrm{I}+\mathrm{A}}{2}=-\chi$

$\eta=\frac{1}{2}\left(\frac{\partial^{2} \mathrm{E}}{\partial \mathrm{N}^{2}}\right)_{v(r)}=\frac{\mathrm{I}-\mathrm{A}}{2}$

$\omega=\frac{\mu^{2}}{2 \eta}$

where $\mathrm{E}$ is the energy of the system, $\mathrm{N}$ is the number of electrons, $\mathrm{v}(\mathrm{r})$ is the external potential, $\mathrm{I} \cong-\mathrm{E}_{\text {номо }}$ is the ionization potential and $\mathrm{A} \cong-\mathrm{E}_{\text {LUMO }}$ is the electron affinity. The transfer of electrons between two molecules in a chemical process is facilitated if their chemical potentials are different. An electron migrates from a molecule with a larger $\mu$ to another with a smaller $\mu$. In chemical processes, a molecule with $\mu<0$ is stable and does not decompose spontaneously. The calculation results show that compounds 6-BRB and 5-BRB are electronically stable (see Table 5). Furthermore, we can state that both molecules are hard and not polarizable, i.e., the molecules are resistant to small deformations of their electronic clouds.

Table 5. Reactivity indices for the compounds 6-BRB and 5-BRB were obtained at the CAM-B3LYP/6-311++G(d,p) level of theory

\begin{tabular}{lcc}
\hline Chemical reactivity indices & $\begin{array}{c}6-\mathrm{BRB} / \\
\left(\mathrm{kcal} \mathrm{mol}^{-1}\right)\end{array}$ & $\begin{array}{c}5-\mathrm{BRB} / \\
\left(\mathrm{kcal} \mathrm{mol}^{-1}\right)\end{array}$ \\
\hline Electronegativity $(\chi)$ & 99.92 & 103.25 \\
Chemical potential $(\mu)$ & -99.92 & -103.25 \\
Chemical hardness $(\eta)$ & 80.70 & 81.45 \\
Global electrophilicity $(\omega)$ & 61.86 & 65.44 \\
\hline
\end{tabular}

6-BRB: 6-bromo-2,3-dimethoxybenzaldehyde; 5-BRB: 5-bromo-2,3dimethoxybenzaldehyde.
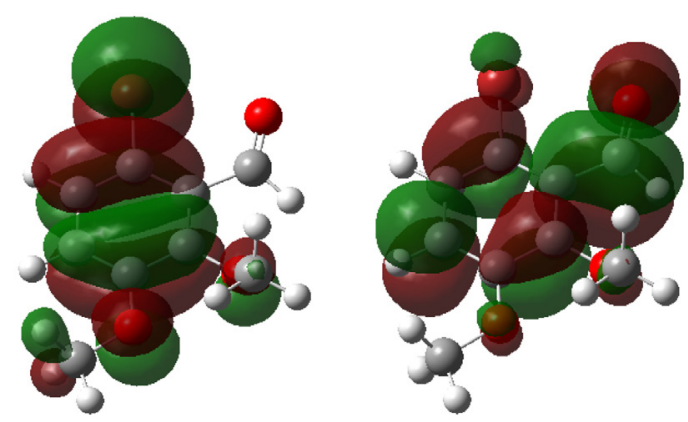

Еномо $=-180.62 \mathrm{kcal} \mathrm{mol}^{-1} \quad$ ELUMO $=-19.22 \mathrm{kcal} \mathrm{mol}^{-1}$

Figure 8. The HOMO and LUMO plot for 6-BRB calculated at CAMB3LYP/6-311++G(d,p) level of theory.

Figure 10 shows the MEP map for 6-BRB. The molecular electrostatic potential map is often used to predict molecular reactivity, and it provides information on a wide range of interactions. ${ }^{47}$ The red regions represent regions with higher electronic charge densities. In these 


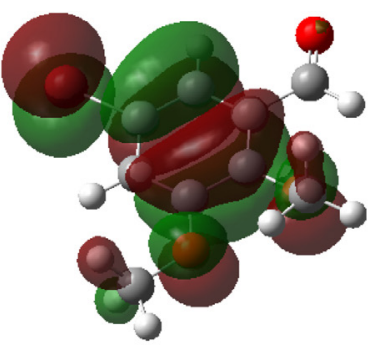

$\mathrm{E}_{\text {HOMO }}=-184.71 \mathrm{kcal} \mathrm{mol}^{-1}$

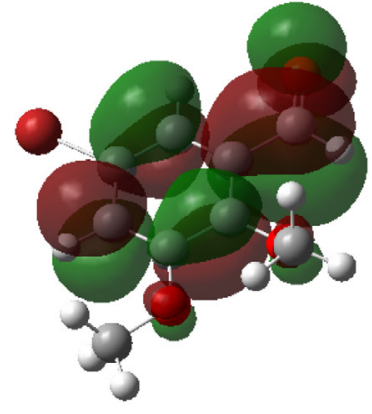

$E_{\text {LUMO }}=-21.80 \mathrm{kcal} \mathrm{mol}^{-1}$
Figure 9. The HOMO and LUMO plot for 5-BRB calculated at CAMB3LYP/6-311++G(d,p) level of theory.

regions, the MEP is negative. The blue areas represent depleted electronic charge density and, therefore, these regions show positive electrostatic potential. Finally, the green spots are associated with null electrostatic potential. Table S2 (SI section) shows the calculated molecular electrostatic potential values for the oxygen and bromine atoms. The bromine atom bonded to the $\mathrm{C}_{6}$ from 6-BRB has much higher electrostatic potential when compared to the compound 5-BRB (see Figures 10c and 10d). The repulsion in the region between $\mathrm{Br}$ and $\mathrm{O}_{1}$ explains the slight increase observed in the $\mathrm{C}_{1}-\mathrm{C}_{7}-\mathrm{O}_{1}$ bond angle. Table $\mathrm{S} 2$ also shows that the oxygen atoms from the carbonyl and methoxy groups are associated with an electrophilic attack. The hydrogen atoms from the methoxy groups are correlated with the nucleophilic attack. The MEP map on the bromine atom shows two regions with values ranging from -19.9 to $2.36 \mathrm{kcal} \mathrm{mol}^{-1}$. This result is interesting in biological systems because the electrostatic potential is valuable in helping to explain the binding of a substrate to its biological receptor site. ${ }^{48-50}$

Figure 11 shows the HOMO and LUMO plots for two dimers taken directly from the crystal structure. These dimers were chosen because they represent the most important interactions observed for the compound 6-BRB in the solid state.

The $\mathrm{C}_{6}-\mathrm{Br} \cdots \mathrm{Br}-\mathrm{C}_{6}$ interaction is the main interaction observed for the first dimer (Figure 11a), and the dominant interaction for the second dimer is $\mathrm{C}_{8}-\mathrm{H} \cdots \mathrm{O}_{2}-\mathrm{C}_{8}$ (Figure 11b). The first interaction is interesting since it occurs frontally between the bromine atoms of the molecules. The MEP map also shows that the $\mathrm{Br} \cdots \mathrm{Br}$ interaction induces the polarization of the electronic clouds of the molecules. The MEP map also shows that the $\mathrm{O}_{2}$ and $\mathrm{O}_{3}$ atoms of the aromatic ring methoxy groups form an electronically charged surface on one side of the molecule. In contrast, on the other side, the electronic population is depleted by the presence of the off-axis methyl group of the molecule, justifying the interaction.

The calculated $\mathrm{C}_{6}-\mathrm{Br} \cdots \mathrm{Br}-\mathrm{C}_{6}$ and $\mathrm{C}_{8}-\mathrm{H} \cdots \mathrm{O}_{2}-\mathrm{C}_{8}$ interactions are respectively -0.47 and $-1.51 \mathrm{kcal} \mathrm{mol}^{-1}$,

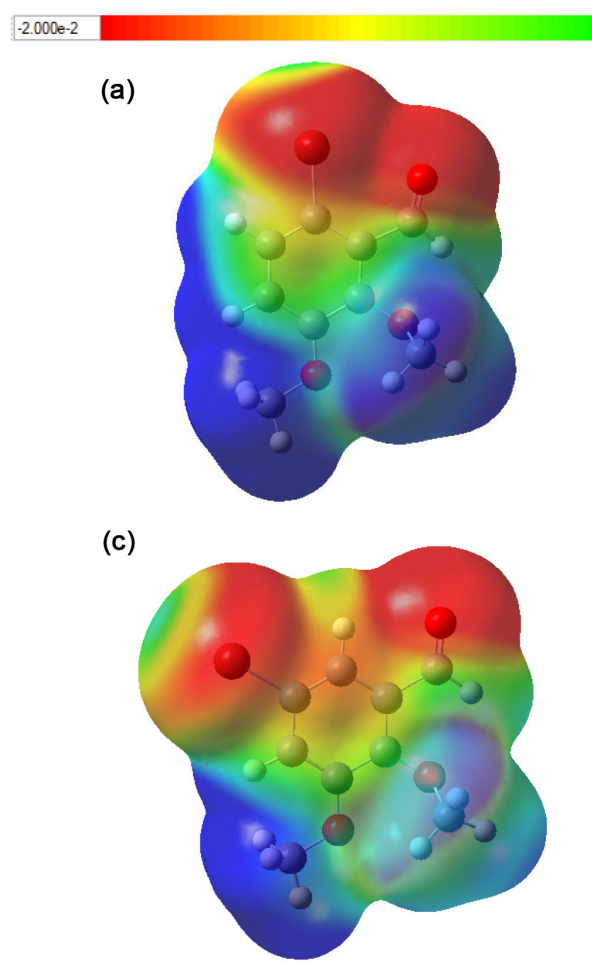

(b)

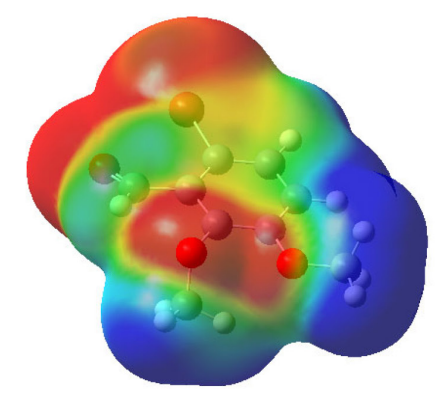

(d)

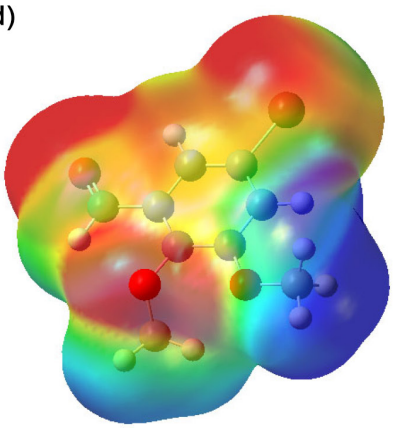

Figure 10. MEP surface at $\rho(\mathbf{r})=4.0 \times 10^{-4}$ electrons Bohr ${ }^{-1}$ contour of the total self consistent field (SCF) electronic density for 6-BRB (a) and (b), and for 5-BRB (c) and (d) carried out at the CAMB3LYP/6-311++ G(d,p) level. 


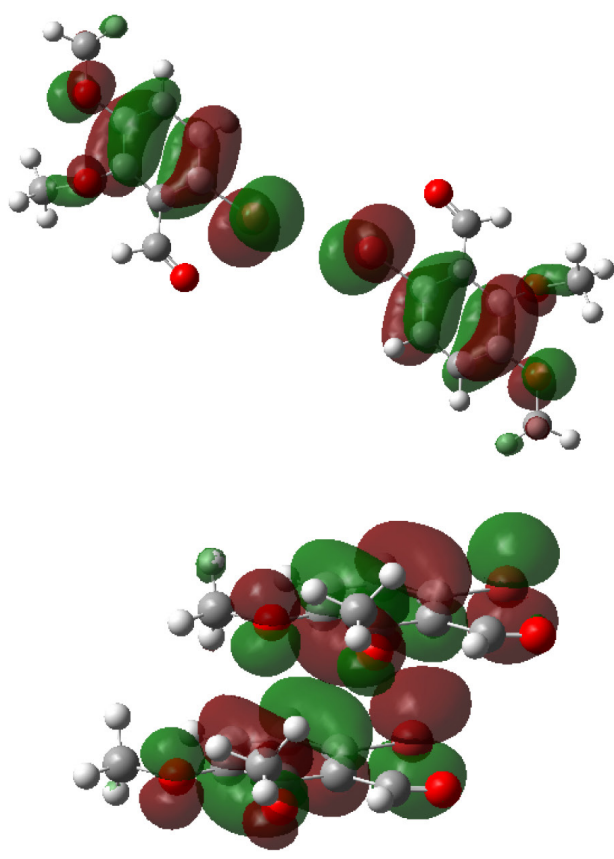

(a)

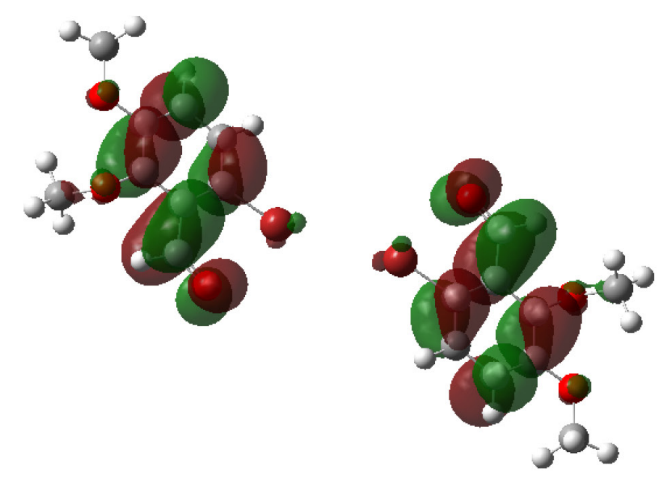

(b)

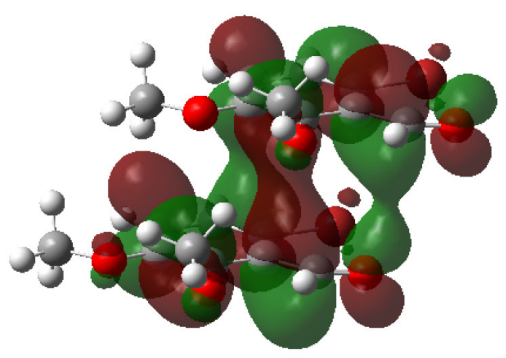

Figure 11. Plotting of HOMO (left) and LUMO (right) and the interaction energies for selected dimers of 6-BRB at the CAM-B3LYP/6-311++G(d,p) level of theory. The interaction energies were corrected by the counterpoise method. (a) $\mathrm{C}_{6}-\mathrm{Br} \cdots \mathrm{Br}-\mathrm{C}_{6}$; (b) $\mathrm{C}_{8}-\mathrm{H} \cdots \mathrm{O}_{2}-\mathrm{C}_{8}$.

corrected by the counterpoise method. ${ }^{51}$ Therefore, the later interaction is the main driving force for the molecular assembling in the crystal. Table 6 shows the natural bond orbital ${ }^{44,45}$ analysis for the two 6-BRB selected dimers. The hyperconjugation energy due to electron delocalization between occupied bonding orbitals (donor) and unoccupied antibonding orbitals (acceptor) helps to stabilize the dimer interaction. The hyperconjugation energies were obtained by the second order perturbation energy equation. ${ }^{45}$

$\mathrm{E}_{\mathrm{i} \rightarrow \mathrm{j}^{*}}^{2}=-\mathrm{n}_{\sigma} \frac{\left\langle\sigma_{\mathrm{i}}|\hat{\mathrm{F}}| \sigma_{\mathrm{j}}^{*}\right\rangle^{2}}{\varepsilon_{\mathrm{j}^{*}}-\varepsilon_{\mathrm{i}}}=-\mathrm{n}_{\sigma} \frac{\mathrm{F}_{\mathrm{ij}}^{2}}{\varepsilon_{\mathrm{j}^{*}}-\varepsilon_{\mathrm{i}}}$

where $\langle\sigma|F| \sigma\rangle^{2}$ or $\mathrm{F}_{\mathrm{ij}}{ }^{2}$ is the Fock matrix element between the $\mathrm{i}$ and $\mathrm{j}$ natural bond orbitals, $\varepsilon_{\sigma^{*}}$ is the energy of the $\sigma^{*}$ antibonding orbital and $\varepsilon_{\sigma}$ is the energy of the bonding orbital $\sigma, \mathrm{n}_{\sigma}$ stands for the population occupation of the donor orbital. For the $\mathrm{C}_{6}-\mathrm{Br} \cdots \mathrm{Br}-\mathrm{C}_{6}$ interaction, we observed that the $\sigma$ bonding orbital of $\mathrm{C}_{6}-\mathrm{Br}$ from one molecular unit hyperconjugates with the $\sigma^{*}$ antibonding orbital of $\mathrm{C}_{6}-\mathrm{Br}$ of the other molecular unit with a second-order perturbative energy of $0.06 \mathrm{kcal} \mathrm{mol}^{-1}$. The $\eta_{1}(\mathrm{Br}), \eta_{2}(\mathrm{Br})$, and $\eta_{3}(\mathrm{Br})$ lone pair orbitals of the $\mathrm{Br}$ from unit 1 hyperconjugates with the $\sigma^{*}$ antibonding orbital of $\mathrm{C}_{6}-\mathrm{Br}$ of unit 2 , with hyperconjugation energies $0.44,0.26$, and $0.17 \mathrm{kcal} \mathrm{mol}^{-1}$, respectively. The same hyperconjugation behavior was observed from unit 2 to unit 1 for $\mathrm{C}_{6}-\mathrm{Br} \cdots \mathrm{Br}-\mathrm{C}_{6}$ interaction. For the $\mathrm{C}_{8}-\mathrm{H} \cdots \mathrm{O}_{2}-\mathrm{C}_{8}$ interaction, the most important contribution to the hyperconjugation from unit 1 to unit 2 is $\pi\left(\mathrm{C}_{1}-\mathrm{C}_{2}\right) \rightarrow \pi^{*}\left(\mathrm{C}_{3}-\right.$ $\left.\mathrm{C}_{4}\right)$ and $\pi\left(\mathrm{C}_{5}-\mathrm{C}_{6}\right) \rightarrow \pi^{*}\left(\mathrm{C}_{3}-\mathrm{C}_{4}\right)$ with hyperconjugation energies of 0.16 and $0.13 \mathrm{kcal} \mathrm{mol}^{-1}$, respectively. From unit 2 to unit 1, the most significant contribution is the hyperconjugation $\eta_{2}\left(\mathrm{O}_{3}\right) \rightarrow \sigma^{*}\left(\mathrm{C}_{8}-\mathrm{H}\right)$ with second-order perturbation energy of $0.1 \mathrm{kcal} \mathrm{mol}^{-1}$. In general, interactions between NBO in intramolecular interactions present high $\mathrm{E}_{\mathrm{i} \rightarrow \mathrm{j}^{*}}^{2}$ values, while in intermolecular interactions, $\mathrm{E}_{\mathrm{i} \rightarrow \mathrm{j}^{*}}^{2}$ values are very small. This means that the latter are less stable than to the former. ${ }^{52-54}$

The Laplacian sign of the electronic density $\nabla^{2} \rho(\mathbf{r})$ at bond critical point $(\mathrm{BCP})$ is directly correlated with the electronic density between two nuclear attractors in a bond. If $\nabla^{2} \rho(\mathbf{r})>0$ and $\rho(\mathbf{r})<0.1$ at the BCP, where nuclear attractors support the entire charge concentration; then the interaction is classified as a closed-shell interaction (ionic, van der Waals interactions, or hydrogen bonds)..$^{55}$ If $\nabla^{2} \rho(\mathbf{r})<0$ and $\rho(\mathbf{r})>0.2$, the electronic charge is accumulated at the BCP; then the interaction is classified as covalent. Finally, if $0.1<\rho(\mathbf{r})<0.2$ and $\nabla^{2} \rho(\mathbf{r})<0$, the interaction is classified as partially covalent; but if $\nabla^{2} \rho(\mathbf{r})>0$ at the BCP, then we have a hydrogen bond and di-hydrogen bond interactions.

The QTAIM analysis shows that the intermolecular interactions for the compound 6-BRB in the crystals have low intensity. Table 7 shows the topological parameters $\rho_{\mathrm{BCP}}$ and $\nabla^{2} \rho_{\mathrm{BCP}}$ calculated at the bond critical points. Figure 12 shows the molecular graph for 6-BRB with the bond paths 
Table 6. Second-order perturbation theory analysis in the NBO basis obtained at the CAM-B3LYP/6-311G(d,p) level of theory for 6-BRB

\begin{tabular}{|c|c|c|c|c|c|c|c|}
\hline & Donor (i) & Occupancy (i) & Acceptor (j) & Occupancy (j) & $\mathrm{E}^{2} /\left(\mathrm{kcal} \mathrm{mol}^{-1}\right)$ & $E_{j}-E_{i} /$ a.u. & $\mathrm{F}(\mathrm{i}, \mathrm{j}) /$ a.u. \\
\hline & \multicolumn{7}{|c|}{ Interaction $\mathrm{C}_{6}-\mathrm{Br} \ldots \mathrm{Br}-\mathrm{C}_{6}$} \\
\hline \multirow{4}{*}{ Unit 1 to 2} & $\sigma\left(\mathrm{C}_{6}-\mathrm{Br}\right)$ & 1.9841 & \multirow{4}{*}{$\sigma^{*}\left(\mathrm{C}_{6}-\mathrm{Br}\right)$} & \multirow{4}{*}{0.0325} & 0.06 & 0.87 & 0.006 \\
\hline & $\eta_{1}(\mathrm{Br})$ & 1.9932 & & & 0.44 & 1.15 & 0.020 \\
\hline & $\eta_{2}(\mathrm{Br})$ & 1.9720 & & & 0.26 & 0.51 & 0.010 \\
\hline & $\eta_{3}(\mathrm{Br})$ & 1.9297 & & & 0.17 & 0.50 & 0.008 \\
\hline \multirow{5}{*}{ Unit 2 to 1} & $\sigma\left(\mathrm{C}_{6}-\mathrm{Br}\right)$ & 1.9841 & $\sigma^{*}\left(\mathrm{C}_{6}-\mathrm{Br}\right)$ & 0.0325 & 0.06 & 0.87 & 0.006 \\
\hline & $\eta_{1}(\mathrm{Br})$ & 1.9932 & $\sigma^{*}\left(\mathrm{C}_{6}-\mathrm{Br}\right)$ & 0.0325 & 0.44 & 1.15 & 0.020 \\
\hline & $\eta_{2}(\mathrm{Br})$ & 1.9720 & $\sigma^{*}\left(\mathrm{C}_{6}-\mathrm{Br}\right)$ & 0.0325 & 0.26 & 0.51 & 0.010 \\
\hline & $\eta_{3}(\mathrm{Br})$ & 1.9297 & $\sigma^{*}\left(\mathrm{C}_{6}-\mathrm{Br}\right)$ & 0.0325 & 0.17 & 0.50 & 0.008 \\
\hline & \multicolumn{7}{|c|}{ Interaction $\mathrm{C}_{8}-\mathrm{H} \ldots \mathrm{O}_{2}-\mathrm{C}_{8}$} \\
\hline \multirow{5}{*}{ Unit 1 to 2} & \multirow{2}{*}{$\pi\left(\mathrm{C}_{1}-\mathrm{C}_{2}\right)$} & \multirow{2}{*}{1.6487} & $\pi^{*}\left(\mathrm{C}_{1}-\mathrm{C}_{2}\right)$ & 0.4093 & 0.06 & 0.35 & 0.004 \\
\hline & & & $\pi^{*}\left(\mathrm{C}_{3}-\mathrm{C}_{4}\right)$ & 0.3953 & 0.16 & 0.35 & 0.007 \\
\hline & $\sigma\left(\mathrm{C}_{4}-\mathrm{H}\right)$ & 1.9765 & $\sigma^{*}\left(\mathrm{C}_{9}-\mathrm{H}\right)$ & 0.0193 & 0.06 & 1.09 & 0.007 \\
\hline & $\pi\left(\mathrm{C}_{5}-\mathrm{C}_{6}\right)$ & 1.6931 & $\pi^{*}\left(\mathrm{C}_{3}-\mathrm{C}_{4}\right)$ & 0.3953 & 0.13 & 0.36 & 0.006 \\
\hline & $\eta_{2}(\mathrm{Br})$ & 1.9740 & $\pi^{*}\left(\mathrm{C}_{5}-\mathrm{C}_{6}\right)$ & 0.3629 & 0.08 & 0.39 & 0.006 \\
\hline \multirow{5}{*}{ Unit 2 to 1} & \multirow{2}{*}{$\pi\left(\mathrm{C}_{1}-\mathrm{C}_{2}\right)$} & \multirow{2}{*}{1.6582} & $\pi^{*}\left(\mathrm{C}_{1}-\mathrm{C}_{2}\right)$ & 0.3964 & 0.07 & 0.36 & 0.005 \\
\hline & & & $\pi^{*}\left(\mathrm{C}_{7}-\mathrm{O}_{1}\right)$ & 0.0805 & 0.11 & 0.39 & 0.006 \\
\hline & $\eta_{3}(\mathrm{Br})$ & 1.9318 & $\sigma^{*}\left(\mathrm{C}_{6}-\mathrm{Br}\right)$ & 0.0310 & 0.06 & 0.48 & 0.005 \\
\hline & $\eta_{1}\left(O_{2}\right)$ & 1.9512 & $\sigma^{*}\left(\mathrm{C}_{8}-\mathrm{H}\right)$ & 0.0204 & 0.08 & 1.08 & 0.009 \\
\hline & $\eta_{2}\left(\mathrm{O}_{3}\right)$ & 1.8609 & $\sigma^{*}\left(\mathrm{C}_{8}-\mathrm{H}\right)$ & 0.0204 & 0.10 & 0.92 & 0.009 \\
\hline
\end{tabular}

NBO: natural bond orbitals, $\mathrm{E}^{2}$ : interactive hyperconjugation energy (stabilization energy); $\mathrm{E}_{\mathrm{j}}-\mathrm{E}_{\mathrm{i}}$ : energetic difference between the NBO donor and acceptor orbitals; F(i,j): Fock matrix element between the NBO i and j orbitals; a.u.: atomic units (Hartree atomic units). A hartree is equal to $2625.44 \mathrm{~kJ} \mathrm{~mol}^{-1}$, $627.08 \mathrm{kcal} \mathrm{mol}^{-1}, 27.21 \mathrm{eV}$, and $219474.6 \mathrm{~cm}^{-1}$.

and the bond critical points (BCP). The electronic density $\rho$ at the bond critical point for $\mathrm{Br} \cdots \mathrm{Br}$ interaction is 0.006 a.u., with a positive Laplacian, and the distance between the two halide attractors is $3.54 \AA$. The $\mathrm{C}_{8}-\mathrm{H} \cdots \mathrm{O}_{2}-\mathrm{C}_{8}$ axial interaction electronic densities are 0.011 a.u. and the distance between the two attractors is $2.43 \AA$. In addition, two more BCPs are observed: $\mathrm{C}_{6} \cdots \mathrm{C}_{3}$ and $\mathrm{C}_{4} \cdots \mathrm{C}_{6}$. Both contacts have low $\rho$ values in the intranuclear region. Furthermore, the low total energy of QTAIM value H(r) and the value of the $\mathrm{G} /|\mathrm{H}|>1.0$ indicate that the electronic flux in the internuclear region is very low, resulting in a weak interaction, closed-shell type. ${ }^{56}$ Thus, 6-BRB crystals are formed in such a way that the molecules interact through van der Waals forces.

The $\mathrm{C}_{4}-\mathrm{H} \cdots \mathrm{O}_{1}-\mathrm{C}_{7}, \mathrm{C}_{7}-\mathrm{O}_{1} \cdots \mathrm{H}-\mathrm{C}_{9}$, and $\mathrm{C}_{8}-\mathrm{H} \cdots \mathrm{O}_{2}-\mathrm{C}_{8}$ interactions stabilize the supramolecular arrangement of 5-BRB. In the first interaction (Figure 13a), the high electron density on the $\mathrm{O}_{1}$ atom of the carbonyl group of one molecule (negative electrostatic potential region) attracts another molecule that has depleted electronic density (positive electrostatic potential region). The energy observed for this interaction is $-2.91 \mathrm{kcal} \mathrm{mol}^{-1}$. For the $\mathrm{C}_{7}-\mathrm{O}_{1} \cdots \mathrm{H}-\mathrm{C}_{9}$ (Figure 13b) interaction, the negative electrostatic potential on the $\mathrm{O}_{1}$ atom of the carbonyl group

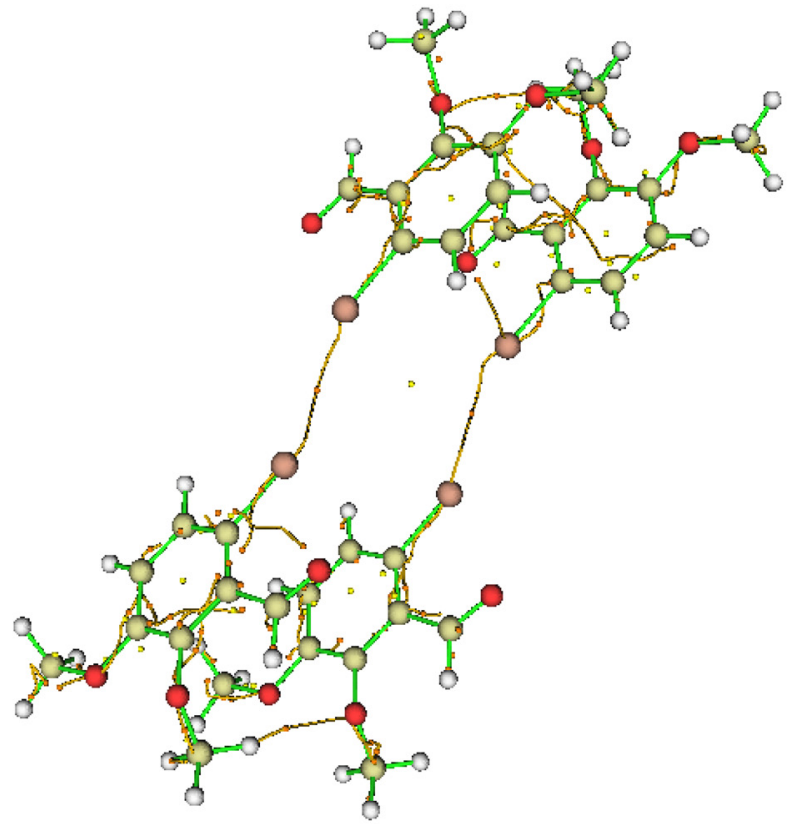

Figure 12. Molecular graph of compound 6-BRB showing the bond path and the bond critical points in tetramer. The input geometry was taken from the crystal data. The bond path (BP) is colored in orange; the attractors are represented by large circles, and the bond critical point (BCP) by small orange circles. The ring critical point (RCP) is represented by the small yellow circle. 
Table 7. Topological properties calculated for the molecular interactions in 6-BRB at the BCP

\begin{tabular}{lcccccc}
\hline Interaction & $\rho(\mathrm{r}) /$ a.u. & $\nabla \rho^{2} /$ a.u. & $\mathrm{G}(\mathrm{r}) /$ a.u. & $\mathrm{U}(\mathrm{r}) /$ a.u. & $\mathrm{H}(\mathrm{r}) /$ a.u. & $\mathrm{G} / \mathrm{UU})$ \\
\hline $\mathrm{C}_{6}-\mathrm{Br} \cdots \mathrm{Br}-\mathrm{C}_{6}$ & 0.006 & 0.023 & 0.004 & -0.003 & 0.0014 & 1.5 \\
$\mathrm{C}_{8}-\mathrm{H} \cdots \mathrm{O}_{2}-\mathrm{C}_{8}$ & 0.011 & 0.035 & 0.008 & -0.008 & 0.0005 & 1.1 \\
$\mathrm{C}_{1} \cdots \mathrm{C}_{3}$ & 0.004 & 0.010 & 0.002 & -0.002 & 0.0004 & 1.2 \\
$\mathrm{C}_{4} \cdots \mathrm{C}_{6}$ & 0.004 & 0.010 & 0.002 & -0.002 & 0.0004 & 1.2 \\
\hline
\end{tabular}

$\rho(r)$ : electronic density; $\nabla \rho^{2}$ : Laplacian electronic density; $\mathrm{G}(\mathrm{r})$ : kinect energy of electronic density; $\mathrm{U}(\mathrm{r})$ : potential energy of electronic density; $\mathrm{H}(\mathrm{r})$ : potential energy of electronic density; G/IUl: ratio kinect and potetial energy; BCP: bond critical point; a.u.: atomic units (Hartree atomic units). A hartree is equal to $2625.44 \mathrm{~kJ} \mathrm{~mol}^{-1}, 627.08 \mathrm{kcal} \mathrm{mol}^{-1}, 27.21 \mathrm{eV}$, and $219474.6 \mathrm{~cm}^{-1}$.

attracts the positive electrostatic potential region on the methyl group $\left(\mathrm{C}_{9}\right)$ of the second molecule, as shown by the MEP map (Figure 10). The energy for this interaction corrected by the counterpoise method is $-1.95 \mathrm{kcal} \mathrm{mol}^{-1}$. The $\mathrm{C}_{8}-\mathrm{H} \cdots \mathrm{O}_{2}-\mathrm{C}_{8}$ (Figure 13c) axial interaction occurs in the region with negative electrostatic potential on the $\mathrm{O}_{2}$ atom, with a positive electrostatic potential region on the methyl group from another molecular. The calculated complexation energy is $-1.30 \mathrm{kcal} \mathrm{mol}^{-1}$.

The NBOs analysis show that the hyperconjugation energies $\mathrm{E}_{\mathrm{i} \rightarrow \mathrm{j}}^{2}$ are very small for these interactions (see Table 8); that is, the donor ligand orbitals (Lewis type) hyperconjugate very weakly with the acceptor antibonding orbitals (non-Lewis type). Therefore, the interactions that occur in the crystals of the 5-BRB are weak. For the dimer shown in Figure 13a, two hyperconjugations were observed between the lone pair orbitals from the $\mathrm{O}_{1}$ atom with the $\sigma^{*}$ antibonding orbital of the $\mathrm{C}_{4}-\mathrm{H}$ bond; that is, $\eta_{1}\left(\mathrm{O}_{1}\right) \rightarrow \sigma^{*}\left(\mathrm{C}_{4}-\mathrm{H}\right)$ and $\eta_{2}\left(\mathrm{O}_{1}\right) \rightarrow \sigma^{*}\left(\mathrm{C}_{4}-\mathrm{H}\right)$ with hyperconjugation energies of 0.09 and $0.77 \mathrm{kcal} \mathrm{mol}^{-1}$, respectively. Lone pairs from the $\mathrm{O}_{1}$ atom also hyperconjugate with the $\mathrm{C}_{9}-\mathrm{H} \sigma^{*}$ antibonding orbitals: $\eta_{1}\left(\mathrm{O}_{1}\right) \rightarrow \sigma^{*}\left(\mathrm{C}_{9}-\mathrm{H}\right)$ and $\eta_{2}\left(\mathrm{O}_{1}\right) \rightarrow \sigma^{*}\left(\mathrm{C}_{9}-\mathrm{H}\right)$ with hyperconjugation energies of 0.89 and $0.10 \mathrm{kcal} \mathrm{mol}^{-1}$. For the dimer depicted in Figure 13b, the most important hyperconjugation occurs between the $\mathrm{C}_{7}-\mathrm{O}_{1} \pi$ bonding orbital with the $\sigma^{*}$ orbital antibonding of $\mathrm{C}_{9}-\mathrm{H}$ with $1.01 \mathrm{kcal} \mathrm{mol}^{-1}$. For the dimer shown in Figure 13c, we

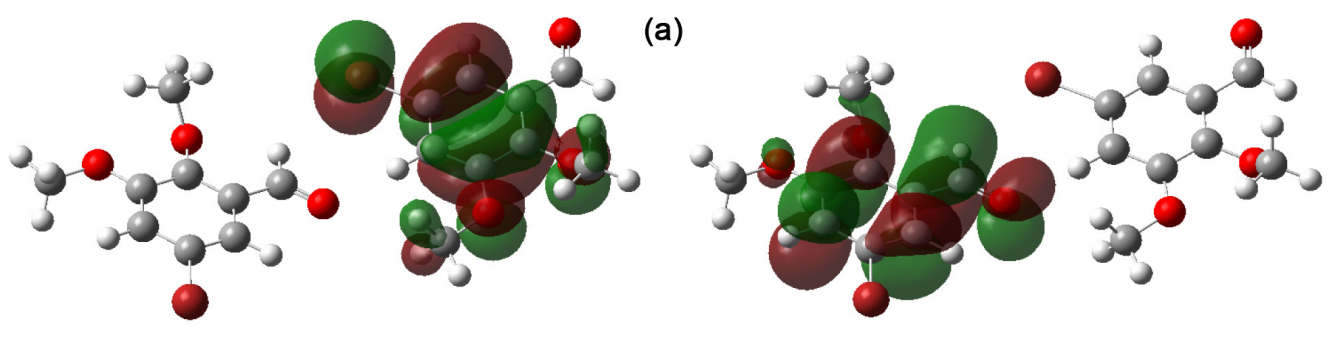

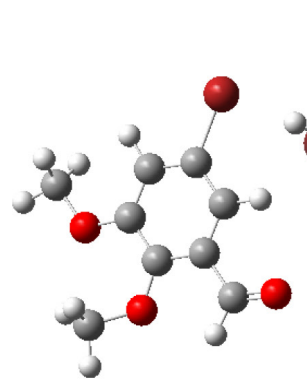
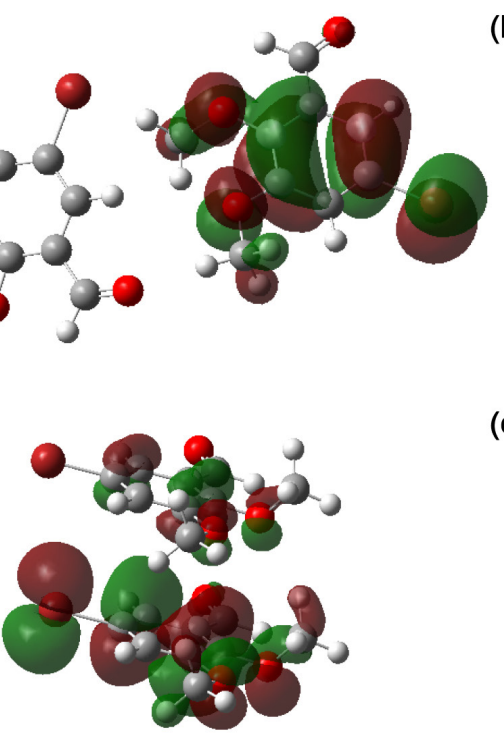

(b)

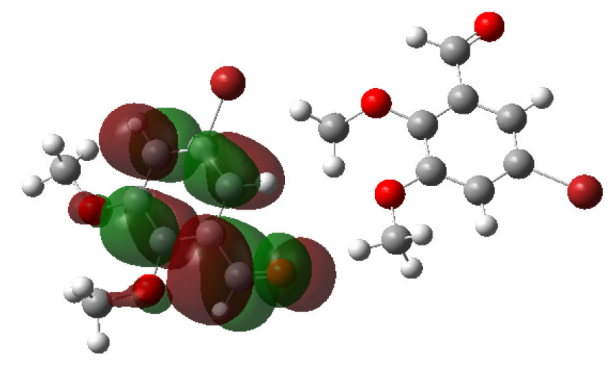

(c)

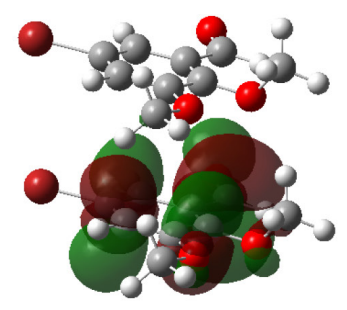

Figure 13. Plotting of HOMO (left) and LUMO (right) and the interaction energies for selected dimers of 5-BRB at the CAM-B3LYP/6-311++G(d,p) level of theory. The interaction energies were corrected by the counterpoise method. (a) $\mathrm{C}_{4}-\mathrm{H} \cdots \mathrm{O}_{1}-\mathrm{C}_{7} ;$ (b) $\mathrm{C}_{7}-\mathrm{O}_{1} \cdots \mathrm{H}-\mathrm{C}_{9} ;$ (c) $\mathrm{C}_{8}-\mathrm{H} \cdots \mathrm{O}_{2}-\mathrm{C}_{8}$. 
Table 8. Second-order perturbation theory analysis in an NBO basis obtained at the CAM-B3LYP/6-311G(d,p) level of theory for 5-BRB

\begin{tabular}{|c|c|c|c|c|c|c|c|}
\hline & Donor (i) & Occupancy (i) & Acceptor (j) & Occupancy (j) & $\mathrm{E}^{2} /\left(\mathrm{kcal} \mathrm{mol}^{-1}\right)$ & $E_{j}-E_{i} /$ a.u. & $\mathrm{F}(\mathrm{i}, \mathrm{j}) /$ a.u. \\
\hline & \multicolumn{7}{|c|}{ Interaction $1 \mathrm{C}_{4}-\mathrm{H} \cdots \mathrm{O}_{1}-\mathrm{C}_{7}$} \\
\hline \multirow{2}{*}{ Unit 1 to 2} & $\eta_{2}(\mathrm{Br})$ & 1.9770 & $\sigma^{*}\left(\mathrm{C}_{7}-\mathrm{H}\right)$ & 0.0294 & 0.18 & 1.18 & 0.013 \\
\hline & & & $\pi^{*}\left(\mathrm{C}_{7}-\mathrm{O}_{1}\right)$ & 0.0889 & 0.20 & 0.40 & 0.008 \\
\hline \multirow{3}{*}{ Unit 2 to 1} & $\eta_{1}\left(O_{1}\right)$ & 1.9845 & $\sigma^{*}\left(\mathrm{C}_{4}-\mathrm{H}\right)$ & 0.0590 & 0.09 & 1.62 & 0.011 \\
\hline & $\eta_{2}\left(O_{1}\right)$ & 1.9167 & $\sigma^{*}\left(\mathrm{C}_{4}-\mathrm{H}\right)$ & 0.0147 & 0.77 & 1.21 & 0.028 \\
\hline & \multicolumn{7}{|c|}{ Interaction $\mathrm{C}_{7}-\mathrm{O}_{1} \cdots \mathrm{H}-\mathrm{C}_{9}$} \\
\hline \multirow{3}{*}{ Unit 1 to 2} & $\pi\left(\mathrm{C}_{7}-\mathrm{O}_{1}\right)$ & 1.9797 & $\sigma^{*}\left(\mathrm{C}_{9}-\mathrm{H}\right)$ & 0.0126 & 0.61 & 1.24 & 0.025 \\
\hline & $\eta_{1}\left(O_{1}\right)$ & 1.9783 & $\sigma^{*}\left(\mathrm{C}_{9}-\mathrm{H}\right)$ & 0.0126 & 0.89 & 1.55 & 0.03 \\
\hline & $\eta_{2}\left(O_{1}\right)$ & 1.9007 & $\sigma^{*}\left(\mathrm{C}_{9}-\mathrm{H}\right)$ & 0.0126 & 0.10 & 1.13 & 0.010 \\
\hline \multirow[t]{2}{*}{ Unit 2 to 1} & $\sigma\left(\mathrm{C}_{9}-\mathrm{H}\right)$ & 1.9899 & $\pi^{*}\left(\mathrm{C}_{7}-\mathrm{O}_{1}\right)$ & 0.0902 & 0.05 & 0.68 & 0.010 \\
\hline & \multicolumn{7}{|c|}{ Interaction $\mathrm{C}_{8}-\mathrm{H} \cdots \mathrm{O}_{2}-\mathrm{C}_{8}$} \\
\hline \multirow{4}{*}{ Unit 1 to 2} & $\pi\left(\mathrm{C}_{1}-\mathrm{C}_{2}\right)$ & 1.6711 & $\pi^{*}\left(\mathrm{C}_{1}-\mathrm{C}_{2}\right)$ & 0.3783 & 0.14 & 0.36 & 0.007 \\
\hline & $\pi\left(\mathrm{C}_{3}-\mathrm{C}_{4}\right)$ & 1.7017 & $\sigma^{*}\left(\mathrm{C}_{9}-\mathrm{H}\right)$ & 0.0137 & 0.13 & 1.03 & 0.011 \\
\hline & $\eta_{3}(\mathrm{Br})$ & 1.9466 & $\pi^{*}\left(\mathrm{C}_{3}-\mathrm{C}_{4}\right)$ & 0.3667 & 0.18 & 0.39 & 0.008 \\
\hline & & & $\pi^{*}\left(\mathrm{C}_{5}-\mathrm{C}_{6}\right)$ & 0.3343 & 0.09 & 0.40 & 0.006 \\
\hline \multirow{5}{*}{ Unit 2 to 1} & $\eta_{1}\left(O_{2}\right)$ & 1.9335 & $\pi^{*}\left(\mathrm{C}_{8}-\mathrm{O}_{2}\right)$ & 0.0811 & 0.06 & 0.59 & 0.006 \\
\hline & $\eta_{2}\left(O_{2}\right)$ & 1.9205 & $\sigma^{*}\left(\mathrm{C}_{12}-\mathrm{H}\right)$ & 0.0130 & 0.99 & 1.23 & 0.032 \\
\hline & $\pi\left(\mathrm{C}_{1}-\mathrm{C}_{2}\right)$ & 1.9728 & $\pi^{*}\left(\mathrm{C}_{1}-\mathrm{C}_{2}\right)$ & 0.3693 & 0.11 & 0.38 & 0.006 \\
\hline & & & $\pi^{*}\left(\mathrm{C}_{5}-\mathrm{C}_{6}\right)$ & 0.3383 & 0.16 & 0.37 & 0.007 \\
\hline & $\pi\left(\mathrm{C}_{3}-\mathrm{C}_{4}\right)$ & 1.6950 & $\pi^{*}\left(\mathrm{C}_{5}-\mathrm{C}_{6}\right)$ & 0.3383 & 0.11 & 0.39 & 0.006 \\
\hline
\end{tabular}

NBO: natural bond orbitals, $E^{2}$ : interactive hyperconjugation energy (stabilization energy); $E_{j}-E_{i}$ : energetic difference between the NBO donor and acceptor orbitals; F(i,j): Fock matrix element between the NBO i and j orbitals; a.u.: atomic units (Hartree atomic units). A hartree is equal to $2625.44 \mathrm{~kJ}^{\mathrm{mol}}{ }^{-1}$, $627.08 \mathrm{kcal} \mathrm{mol}^{-1}, 27.21 \mathrm{eV}$, and $219474.6 \mathrm{~cm}^{-1}$.

found two significant hyperconjugations between the lone pair orbitals from $\mathrm{O}_{2}$ atom and the $\sigma^{*}$ antibonding orbital of $\mathrm{C}_{12}-\mathrm{H}, \eta_{2}\left(\mathrm{O}_{2}\right) \rightarrow \sigma^{*}\left(\mathrm{C}_{12} \mathrm{H}\right)$ with hyperconjugation energy of $0.99 \mathrm{kcal} \mathrm{mol}^{-1}$, and with the $\pi^{*}$ antibonding orbital of $\mathrm{C}_{8}-\mathrm{O}_{2}, \eta_{1}\left(\mathrm{O}_{2}\right) \rightarrow \pi^{*}\left(\mathrm{C}_{8} \mathrm{O}_{2}\right)$ with hyperconjugation energy of $0.06 \mathrm{kcal} \mathrm{mol}^{-1}$.

The topological analysis of the molecular system of the compound 5-BRB (Table 9) shows that the molecular electronic densities calculated at the bond critical points (BCP) have small values with $\nabla^{2} \rho_{\mathrm{BCP}}>0$ for all critical points analyzed. The values obtained for $\mathrm{H}(\mathbf{r})$ ca. 0 , indicating low intensity interactions between nuclear attractors. These results indicate that the interactions between the molecules in the crystal are all of the closedshell type, so the molecules interact by van der Waals forces to form the tetramer. Figure 14a shows the bond paths and the bond critical points for a tetramer taken from the crystal, and Figure $14 \mathrm{~b}$ shows a dimer from the second packaging layer. The electronic density $\rho$ at the BCP between $\mathrm{H}$ and $\mathrm{O}$ atoms for the $\mathrm{C}_{4}-\mathrm{H} \cdots \mathrm{O}_{1}-\mathrm{C}_{7}$ interaction is 0.029 a.u., and the distance between the attractors is $2.52 \AA$. The electronic density at the $\mathrm{BCP}$ for the $\mathrm{C}_{7}-\mathrm{O}_{1} \cdots \mathrm{H}-\mathrm{C}_{9}$ interaction is 0.027 a.u., and the distance between the attractors is $2.38 \AA$. These interactions are bifurcated, with the $\mathrm{O}_{1}$ atom from the carbonyl group interacting with two hydrogens from other molecular units.

Figure $14 \mathrm{~b}$ shows the structure of the second layer of the packaging of the tetramer structure of 5-BRB. The electronic density at $\mathrm{BCP}$ for the $\mathrm{C}_{8}-\mathrm{H} \cdots \mathrm{O}_{2}-\mathrm{C}_{8}$ interaction shown in Figure $14 \mathrm{~b}$ is 0.010 a.u., and the distance between the attractors is $2.47 \AA$. Interestingly, the $\mathrm{Br}$ atom from one molecular unit interacts in a bifurcated way with a second molecular unit. The first BCP appears in the $\mathrm{Br} \cdot \mathrm{H}-\mathrm{C}_{7}$ intranuclear region with an electronic density of 0.032 a.u. and with internuclear attractors' distance of $3.22 \AA$. The second $\mathrm{BCP}$ appears in the intranuclear region of $\mathrm{Br} \cdots \mathrm{H}-\mathrm{C}_{8}$ interaction with an electronic density of 0.031 a.u. and the attractors' distance of $3.41 \AA$. In the layered structure, two BCPs for the $\mathrm{Br}$ atom appear: the first one appears in the intranuclear $\mathrm{Br} \cdots \mathrm{Br}$ region with an electronic density of 0.005 a.u. The second one is located on the $B r \cdots C_{4}$ path with electronic density of 0.004 a.u.

The molecular topology analysis shows that the aromatic rings of the 5-BRB molecules in the crystals interact weakly. This interaction is characterized by a BCP on the $\mathrm{C}_{4} \cdots \mathrm{C}_{4}$ path with an electron density of 0.005 a.u. $A$ critical cage point (CCP) is also observed in tetramer layers with an electronic density of 0.002 a.u. 


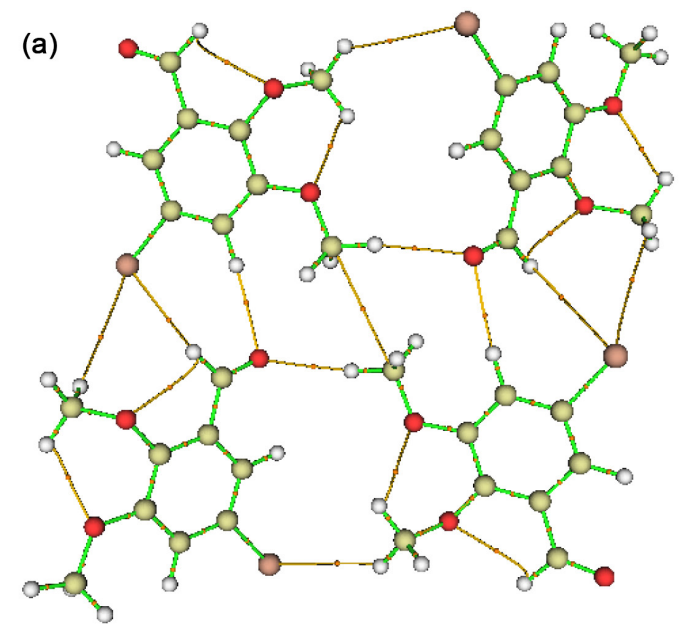

(b)

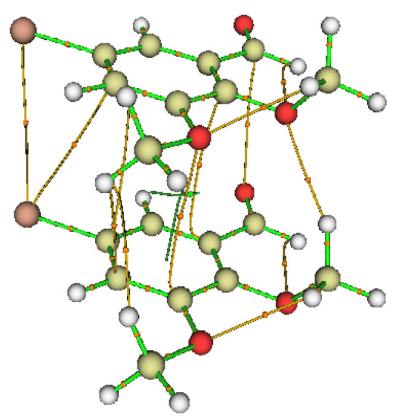

Figure 14. Molecular graph showing the bond paths and the bond critical points for the 5-BRB tetramer taken from the crystal data. The bond paths (BP) are colored in orange lines; the attractors are represented by the large circles, and the bond critical point (BCP) by the small orange circles. The cage critical point (CCP) is represented by the small green circle. (a) Tetramer; (b) second layer of the packaging.

Table 9. Topological properties calculated for the molecular interactions in 5-BRB at the BCP

\begin{tabular}{|c|c|c|c|c|c|c|c|}
\hline & Interaction & $\rho(\mathrm{r}) /$ a.u. & $\nabla \rho^{2} /$ a.u. & G(r) / a.u. & $\mathrm{U}(\mathrm{r})$ / a.u. & $\mathrm{H}(\mathrm{r}) /$ a.u. & $\mathrm{G} / \mathrm{IUI}$ \\
\hline \multirow{9}{*}{ Tetramer structure } & $\mathrm{C}_{4}-\mathrm{H} \cdots \mathrm{O}_{1}-\mathrm{C}_{7}$ & 0.029 & 0.042 & 0.012 & -0.013 & -0.0010 & 0.9 \\
\hline & $\mathrm{C}_{7}-\mathrm{O} 1 \cdots \mathrm{H}-\mathrm{C}_{9}$ & 0.027 & 0.024 & 0.009 & -0.013 & -0.0033 & 0.7 \\
\hline & $\mathrm{Br} \cdots \mathrm{H}-\mathrm{C}_{7}$ & 0.032 & 0.023 & 0.008 & -0.011 & -0.0027 & 0.8 \\
\hline & $\mathrm{Br} \cdots \mathrm{H}-\mathrm{C}_{8}$ & 0.031 & 0.025 & 0.008 & -0.009 & -0.0013 & 0.9 \\
\hline & $\mathrm{C}_{8}-\mathrm{H} \cdots \mathrm{Br}$ & 0.016 & 0.018 & 0.006 & -0.006 & -0.0009 & 0.9 \\
\hline & $\mathrm{C}_{9} \cdots \mathrm{C}_{9}$ & 0.021 & 0.021 & 0.007 & -0.009 & -0.0019 & 0.8 \\
\hline & $\mathrm{C}_{9}-\mathrm{H} \cdots \mathrm{O}_{1}-\mathrm{C}_{7}$ & 0.039 & 0.021 & 0.013 & -0.021 & -0.0077 & 0.6 \\
\hline & $\mathrm{C}_{7}-\mathrm{H} \cdots \mathrm{Br}$ & 0.035 & 0.027 & 0.010 & -0.012 & -0.0029 & 0.8 \\
\hline & $\mathrm{C}_{8}-\mathrm{H} \cdots \mathrm{Br}$ & 0.022 & 0.028 & 0.008 & -0.008 & -0.0007 & 0.9 \\
\hline \multirow{7}{*}{ Layer structure } & $\mathrm{C}_{8}-\mathrm{H} \cdots \mathrm{O}_{2}-\mathrm{C}_{8}$ & 0.010 & 0.033 & 0.008 & -0.007 & 0.0007 & 1.1 \\
\hline & $\mathrm{C}_{7}-\mathrm{O}_{1} \cdots \mathrm{C}_{7}-\mathrm{O}_{1}$ & 0.003 & 0.010 & 0.002 & -0.001 & 0.0006 & 1.4 \\
\hline & $\mathrm{Br} \cdots \mathrm{C}_{4}$ & 0.004 & 0.012 & 0.001 & -0.002 & 0.0005 & 0.6 \\
\hline & $\mathrm{Br} \cdots \mathrm{Br}$ & 0.005 & 0.013 & 0.003 & -0.002 & 0.0005 & 1.2 \\
\hline & $\mathrm{C}_{9}-\mathrm{H} \cdots \mathrm{H}-\mathrm{C}_{9}$ & 0.005 & 0.016 & 0.003 & -0.002 & -0.0019 & 1.5 \\
\hline & $\mathrm{C}_{4}-\mathrm{H}-\mathrm{C}_{9}$ & 0.004 & 0.012 & 0.003 & -0.002 & 0.0005 & 1.2 \\
\hline & $\mathrm{C}_{4} \cdots \mathrm{C}_{5}$ & 0.005 & 0.012 & 0.003 & -0.002 & 0.0005 & 1.2 \\
\hline
\end{tabular}

$\rho(r)$ : electronic density; $\nabla \rho^{2}$ : Laplacian electronic density; $G(r)$ : kinect energy of electronic density; $U(r)$ : potential energy of electronic density; $H(r)$ : potential energy of electronic density; G/IUl: ratio kinect and potetial energy; BCP: bond critical point; a.u.: atomic units (Hartree atomic units). A hartree is equal to $2625.44 \mathrm{~kJ} \mathrm{~mol}^{-1}, 627.08 \mathrm{kcal} \mathrm{mol}^{-1}, 27.21 \mathrm{eV}$, and $219474.6 \mathrm{~cm}^{-1}$.

\section{Conclusions}

The compound 6-BRB is crystallized in the $\mathrm{P} 2{ }_{1} / \mathrm{n}$ special group, with four molecules in the unit cell. Its crystalline state is stabilized by $\mathrm{C}-\mathrm{H} \cdots \mathrm{O}$ and $\mathrm{Br} \cdots \mathrm{Br}$ interactions and $\pi \cdots \pi$ stacking. The compound 5-BRB also crystallized in the $\mathrm{P} 2_{1} / \mathrm{n}$ special group. With four molecules in the unit cell, however, its crystalline state is stabilized by $\mathrm{C}-\mathrm{H} \cdots \mathrm{O}$ interactions and $\pi \cdots \pi$ stacking. Both interactions were confirmed by their HS and shape index. Theoretical calculations showed that the molecules of the compounds are electronically stable, and that the carbonyl groups have electrophilic activity in both compounds. In their respective crystals, the molecules interact through low-energy interactions, thus being closed-shell, interactions and it is noteworthy that the values obtained for these energies are only an estimate for the crystal system. NBO analyses showed that the donor orbitals interact weakly with the acceptor orbitals in these interactions. Finally, molecular topology showed that electronic charge densities are low in the internuclear regions of the interaction sites, in order to present a van der Waals character. 


\section{Supplementary Information}

Crystallographic data for the structures in this work were deposited in the Cambridge Crystallographic Data Centre as supplementary publication number CCDC 2087936 and 2087933. Copies of the data can be obtained, free of charge, via https://www.ccdc.cam.ac.uk.

Supplementary information $\left({ }^{1} \mathrm{H}\right.$ and ${ }^{13} \mathrm{C}$ NMR spectra of 6-BRB; ${ }^{1} \mathrm{H}$ and ${ }^{13} \mathrm{C}$ NMR spectra of 5-BRB; FTIR spectra of 6-BRB and 5-BRB) is available free of charge at http://jbcs.sbq.org.br as PDF file.

\section{Acknowledgments}

This research was developed with the support of the Fundação de Amparo à Pesquisa do Estado de Goiás (FAPEG, Brazil), Conselho Nacional de Desenvolvimento Científico e Tecnológico (CNPq, Brazil), and Consejo Nacional de Ciencia y Tecnología (CONACYT, Mexico). The authors thank the High Performance Computing Center of the Universidade Estadual de Goiás, X-ray and NMR facilities (grant INFR-2014-224405 and INFR-2011-3173395) and Tecnológico Nacional de México (TecNM grant 10160.21-P).

\section{Author Contributions}

I. D. Borges and H. B. Napolitano were responsible for conceptualization, investigation, data curation and project administration; A. Navarrete and G. Aguirre for experimental syntheses, characterization of substances and X-ray crystallography data treatment; A. S. N. Aguiar and S. S. Oliveira for investigation, software and validation; A. J. Camargo and H. B. Napolitano for writing-review visualization and formal analysis funding acquisition. All authors were responsible for writing the original draft and writingreview and editing.

\section{References}

1. Sharp, J. H.; Winson, M. K.; Porter, J. S.; Nat. Prod. Rep. 2007, 24, 659.

2. Ramírez-Osuna, M.; Chávez, D.; Hernández, L.; Molins, E.; Somanathan, R.; Aguirre, G.; Molecules 2005, 10, 295.

3. Ciavatta, M. L.; Lefranc, F.; Vieira, L. M.; Kiss, R.; Carbone, M.; van Otterlo, W. A. L.; Lopanik, N. B.; Waeschenbach, A.; Mar. Drugs 2020, 18, 200.

4. Hashima, H.; Hayashi, M.; Kamano, Y.; Sato, N.; Bioorg. Med. Chem. 2000, 8, 1757.

5. Gardner, Z. S.; Schumacher, T. J.; Ronayne, C. T.; Kumpati, G. P.; Williams, M. J.; Yoshimura, A.; Palle, H.; Mani, C.; Rumbley, J.; Mereddy, V. R.; Bioorg. Med. Chem. Lett. 2021, 45, 128136.
6. Cavallo, G.; Metrangolo, P.; Milani, R.; Pilati, T.; Priimagi, A.; Resnati, G.; Terraneo, G.; Chem. Rev. 2016, 116, 2478.

7. Moorthy, J. N.; Venkatakrishnan, P.; Mal, P.; Dixit, S.; Venugopalan, P.; Cryst. Growth Des. 2003, 3, 581.

8. Hansen, P. E.; Spanget-Larsen, J.; J. Mol. Struct. 2012, $1018,8$.

9. Brugman, S. J. T.; Engwerda, A. H. J.; Kalkman, E.; de Ronde, E.; Tinnemans, P.; Vlieg, E.; Acta Crystallogr., Sect. E: Crystallogr. Commun. 2019, 75, 38.

10. Yadav, M. P. S.; Kumar, A.; Jayarama, A.; Monatsh. Chem. 2016, 147, 1045.

11. Babu, S. S.; Praveen, V. K.; Ajayaghosh, A.; Chem. Rev. 2014, 114, 1973.

12. Legon, A. C.; Phys. Chem. Chem. Phys. 2010, 12, 7736.

13. Lu, Y.-X.; Zou, J.-W.; Wang, Y.-H.; Jiang, Y.-J.; Yu, Q.-S.; J. Phys. Chem. A 2007, 111, 10781.

14. Saneei, A.; Pourayoubi, M.; Jenny, T. A.; Crochet, A.; Fromm, K. M.; Shchegravina, E. S.; Chem. Pap. 2017, 71, 1809.

15. Hardegger, L. A.; Kuhn, B.; Spinnler, B.; Anselm, L.; Ecabert, R.; Stihle, M.; Gsell, B.; Thoma, R.; Diez, J.; Benz, J.; Plancher, J.; Hartmann, G.; Banner, D. W.; Haap, W.; Diederich, F.; Angew. Chem., Int. Ed. 2011, 50, 314.

16. Khera, M.; Goel, N.; J. Mol. Graphics Modell. 2020, 95, 107503.

17. Hohenberg, P.; Kohn, W.; Phys. Rev. 1964, 136, B864.

18. Kohn, W.; Sham, L. J.; Phys. Rev. 1965, 140, A1133.

19. Zhang, G.; Musgrave, C. B.; J. Phys. Chem. A 2007, 111, 1554.

20. Al-Labadi, A. G. M.: Nucleophilic Aromatic Substitution by $\left.{ }^{[18} \mathrm{F}\right]$ Fluoride and Its Applications to the Synthesis of Model Precursors for the Multi-step Synthesis of the PET-Tracer 6-[18F] Fluoro-L-DOP; MSc Dissertation, Tübingen, Germany, 2006, available at https://publikationen.uni-tuebingen.de/xmlui/ handle/10900/48928, accessed in January 2022.

21. CrysAlis PRO, version Pro 1.171.38.46; Rigaku Oxford Diffraction Ltd., England, 2015.

22. Dolomanov, O. V.; Bourhis, L. J.; Gildea, R. J.; Howard, J. A. K.; Puschmann, H.; J. Appl. Crystallogr. 2009, 42, 339.

23. Sheldrick, G. M.; Acta Crystallogr., Sect. C: Struct. Chem. 2015, 71, 3.

24. Sheldrick, G. M.; Acta Crystallogr., Sect. A: Found. Adv. 2015, 71,3 .

25. Farrugia, L. J.; J. Appl. Crystallogr. 1997, 30, 565.

26. Burnett, M. N.; Johnson, C. K.; ORTEP-III: Oak Ridge Thermal Ellipsoid Plot Program for Crystal Structure Illustrations; Oak Ridge, TN, 1996.

27. Macrae, C. F.; Edgington, P. R.; McCabe, P.; Pidcock, E.; Shields, G. P.; Taylor, R.; Towler, M.; van de Streek, J.; J. Appl. Crystallogr. 2006, 39, 453.

28. Spek, A. L.; J. Appl. Crystallogr. 2003, 36, 7.

29. Groom, C. R.; Bruno, I. J.; Lightfoot, M. P.; Ward, S. C.; Acta Crystallogr., Sect. B: Struct. Sci., Cryst. Eng. Mater. 2016, 72, 171. 
30. Turner, M.; McKinnon, J.; Wolff, S.; Grimwood, D.; Spackman, P.; Jayatilaka, D.; Spackman, M.; CrystalExplorer17, University of Western Australia, Australia, 2017.

31. Spackman, M. A.; Jayatilaka, D.; CrystEngComm 2009, 11, 19.

32. McKinnon, J. J.; Jayatilaka, D.; Spackman, M. A.; Chem. Commun. 2007, 3814.

33. Spackman, M. A.; McKinnon, J. J.; CrystEngComm 2002, 4, 378.

34. McKinnon, J. J.; Mitchell, A. S.; Spackman, M. A.; Chem. Commun. 1998, 2071.

35. McKinnon, J. J.; Spackman, M. A.; Mitchell, A. S.; Acta Crystallogr., Sect. B: Struct. Sci. 2004, 60, 627.

36. Frisch, M. J.; Trucks, G. W.; Schlegel, H. B.; Scuseria, G. E.; Robb, M. A.; Cheeseman, J. R.; Scalmani, G.; Barone, V.; Petersson, G. A.; Nakatsuji, H.; Li, X.; Caricato, M.; Marenich, A.; Bloino, J.; Janesko, B. G.; Gomperts, R.; Mennucci, B.; Hratchian, H. P.; Ortiz, J. V.; Izmaylov, A. F.; Sonnenberg, J. L.; Williams-Young, D.; Ding, F.; Lipparini, F.; Egidi, F.; Goings, J.; Peng, B.; Petrone, A.; Henderson, T.; Ranasinghe, D.; Zakrzewski, V. G.; Gao, J.; Rega, N.; Zheng, G.; Liang, W.; Hada, M.; Ehara, M.; Toyota, K.; Fukuda, R.; Hasegawa, J.; Ishida, M.; Nakajima, T.; Honda, Y.; Kitao, O.; Nakai, H.; Vreven, T.; Throssell, K.; Montgomery, J. A.; Peralta Jr., A. E.; Ogliaro, F.; Bearpark, M.; Heyd, J. J.; Brothers, E.; Kudin, K. N.; Staroverov, V. N.; Keith, T.; Kobayashi, R.; Normand, J.; Raghavachari, K.; Rendell, A.; Burant, J. C.; Iyengar, J.; Tomasi, S. S.; Cossi, M.; Millam, J. M.; Klene, M.; Adamo, C.; Cammi, R.; Ochterski, J. W.; Martin, R. L.; Morokuma, K.; Farkas, O.; Foresman, J. B.; Fox, D. J.; Gaussian 09; Gaussian, Inc., Wallingford, 2009.

37. Parr, R. G.; Yang, W.; Hill, C.; Carolina, N.; J. Am. Chem. Soc. 1984, 106, 4049.

38. Parr, R. G.; Szentpály, L. V.; Liu, S.; J. Am. Chem. Soc. 1999, $121,1922$.

39. Náray-Szabó, G.; Ferenczy, G. G.; Chem. Rev. 1995, 95, 829.

40. Matta, C. F.; Bader, R. F. W.; Proteins: Struct., Funct., Genet. 2003, 52,360 .
41. Bader, R. F. W.; Atoms in Molecules - A Quantum Theory; Clarendon Press Publication: Ontario, 1994.

42. Bader, R. F. W.; Acc. Chem. Res. 1985, 18, 9.

43. Lu, T.; Multiwfn, Softw. manual. version 3.7; Beijing Kein Research Center for Natural Sciences, China, 2020.

44. Weinhold, F.; Landis, C. R.; Discovering Chemistry with Natural Bond Orbitals, 1 ${ }^{\text {st }}$ ed.; John Wiley \& Sons, Inc.: USA, 2012.

45. Alabugin, I. V.; Gilmore, K. M.; Peterson, P. W.; Wiley Interdiscip. Rev.: Comput. Mol. Sci. 2011, 1, 109.

46. Duarte, H. A.; Quim. Nova 2001, 24, 501.

47. Politzer, P.; Murray, J. S.; Theor. Chem. Acc. 2002, 108, 134.

48. Weinstein, H.; Osman, R.; Green, J. P.; Topiol, S. In Chemical Applications of Atomic and Molecular Electrostatic Potentials; Springer US: Boston, MA, 1981, p. 309-334.

49. Guha, S.; Majumdar, D.; Bhattacharjee, A. K.; J. Mol. Struct.: THEOCHEM 1992, 256, 61.

50. Pèpe, G.; Siri, D.; Reboul, J.-P.; J. Mol. Struct.: THEOCHEM 1992, 256, 175.

51. van Duijneveldt, F. B.; van de Rijdt, J. G. C. M. D.; van Lenthe, J. H.; Chem. Rev. 1994, 94, 1873.

52. Costa, R. F.; Aguiar, A. S. N.; Borges, I. D.; Ternavisk, R.; Valverde, C.; Camargo, A. J.; Braz, D.; Napolitano, H. B.; Oliveira, S. S.; J. Mol. Model. 2021, 27, 65.

53. Costa, R. F.; Oliveira, M. S.; Aguiar, A. S. N.; Custodio, J. M. F.; di Mascio, P.; Sabino, J. R.; Verde, G. V.; de Souza, J. C. P.; Santin, L. G.; Camargo, A. J.; Barbosa, I. C.; Oliveira, S. S.; Napolitano, H. B.; Crystals 2021, 11, 934.

54. Sosa, G. L.; Peruchena, N. M.; Contreras, R. H.; Castro, E. A.; J. Mol. Struct.: THEOCHEM 2002, 577, 219.

55. Matta, C. F. M.; Boyd, R. J.; The Quantum Theory of Atoms in Molecules; Wiley-VCH: Weinheim, 2007.

56. Tidey, J. P.; Zhurov, V. V; Gianopoulos, C. G.; Hermann, T. S.; Pinkerton, A. A.; J. Phys. Chem. A 2018, 122, 9676.

Submitted: October 16, 2021 Published online: February 1, 2022 